\title{
Los proyectos privatizadores en el agro yucateco, |8|2-1847: ¿causas de la guerra de castas?*
}

\author{
Arturo Güémez Pineda
}

Este artículo presenta una síntesis del liberalismo agrario desarrollado en la península yucateca durante la primera mitad del siglo XIX, haciendo hincapié en los orígenes y consecuencias del proyecto privatizador plasmado en la Ley de Colonización de I84I, con la intención de ofrecer un punto de vista que difiere de aquellos estudios que ven las políticas de enajenación territorial llevadas a efecto en dicho periodo como un proceso lineal y triunfante así como factor principal -o por lo menos como uno de los más poderosos detonantes- de la guerra de castas iniciada en julio de 1847.

This article presents a synthesis of agrarian liberalism developed in the Yucatan Peninsula during the first half of the 19th century, stressing the origins and consequences of the privatizing project set forth in the 184I Laws for Colonization. The aim is to offer a point of view which differs from those studies which regard the policies of territorial dispossession carried out in this period as a lineal and triumphant process and as the main factor - or at least as one of those which triggered off- the War of Castes which broke out in 1847.

ARTURO GÜÉMEZ PINEDA: Universidad Autónoma de Yucatán.

Desacatos, núm. 13, invierno 2003, pp. 60-82.

\footnotetext{
* El presente ensayo es un producto de la investigación "El proyecto liberal agrario y la propiedad comunal en Yucatán. Del derrumbe del centralismo a la guerra de castas (1840-1847)", llevada a efecto por el autor en la Unidad de Ciencias Sociales del Centro de Investigaciones Regionales "Dr. Hideyo Noguchi" de la Universidad Autónoma de Yucatán, que también formó parte del proyecto "Tenencia de la tierra y trabajo indígena en la península de Yucatán", coordinado por el Programa Peninsular del Centro de Investigaciones y Estudios Superiores en Antropología Social.
} 


\section{INTRODUCCIÓN}

$\mathrm{E}$ 1 proceso de privatización de tierras de corte liberal iniciado en 1812, a raíz de las acciones legislativas de las Cortes de Cádiz, fue un fenómeno con resultados heterogéneos en las distintas regiones del México de la primera mitad del siglo XIX. Esto se debió en gran medida a que tanto las leyes emanadas del constitucionalismo gaditano como las de la época del constitucionalismo republicano, en materia de desamortización territorial, dejaron en manos de las élites gobernantes regionales su aplicación de acuerdo con las "condiciones locales". De ese modo, es posible - a través de distintas obras historiográficas - observar en el panorama nacional una gama de situaciones, pues así como hubo regiones donde las tendencias privatizadoras liberales no representaron líneas para las acciones políticas de las élites, como en el caso del valle de Toluca y Chalco, Estado de México, en otras éstas estuvieron inspiradas fundamentalmente en las dos líneas trazadas desde la emisión de las leyes gaditanas: una se refería al reparto de tierras a las familias indígenas, la cual fue adoptada en regiones como Jalisco y Michoacán; la otra, a la venta de tierras comunes y baldías como una de las vías para obtener fondos para el financiamiento de la administración pública o para favorecer a diferentes grupos sociales en la adquisición de tierras y lograr una eventual colonización, como sucedió, sobre todo, en regiones periféricas como Oaxaca, los pueblos serranos de Sonora, la Huasteca potosina ${ }^{1}$ y Yucatán.

El seguimiento de esta última línea por parte de las élites políticas regionales ha sido visto con frecuencia por diversos autores como un factor o causa directa de despojos de tierras comunales e incluso de insurrecciones campesinas o indígenas. En el caso yucateco, por ejemplo, la aplicación de la política de privatización territorial ha sido contemplada (desde la misma historiografía decimonónica hasta la moderna) como una tendencia

${ }^{1}$ Sobre estas apreciaciones véase Menegus, 1995: 7-27; Tutino, 1990(a): 94-134; Frazer, 1972: 615-652; Knowlton, 1978: 24-61; Meyer, 1986: 189211; Franco, 1986: 169-188; Reina, 1989: 19-35; Radding, 1993: 267-292; Márquez, 1986: 201-115. invariable y triunfante y como uno de los motivos, si no es que el principal, de la llamada guerra de castas, sublevación indígena iniciada en julio de 1847 . El gran impacto de esa insurrección en la sociedad yucateca ha propiciado que en diversas obras historiográficas aparezca como un parteaguas del devenir histórico regional del siglo XIX. Desde ese mismo siglo y hasta tiempos muy recientes, ha prevalecido una fuerte tendencia a estudiar o aludir a las relaciones interétnicas coloniales y de la primera mitad del siglo XIX, con el fin de encontrar los orígenes de este conflicto. ${ }^{2}$ Por otra parte, varios estudiosos han privilegiado lo que han considerado la consecuencia más importante del conflicto: la formación de comunidades independientes del gobierno criollo yucateco en la región sudoriental de la península, destacando su prolongada resistencia a lo largo de medio siglo y aludiendo, de un modo u otro, a las características de su organización política-militar, económica y social, así como a las distintas negociaciones que intentaron tanto los representantes del gobierno regional y nacional, y los nexos, negociaciones comerciales y conflictos con el gobierno inglés a través de los colonos de Belice. ${ }^{3}$

Por estas razones, en la investigación de largo aliento, de la que deriva este artículo, tratamos de mantenernos al margen de la determinante de la guerra de castas e intentamos, de manera preferente, abordar el problema de la privatización territorial como un proceso con profundas raíces en las acciones de los pobladores de Yucatán en el pasado — sin olvidar su persistencia, hasta nuestros días, como conflicto en las acciones de sus habitantes-, procurando, además, emprender la identificación y el seguimiento de las continuidades y los cambios de las políticas de privatización en un plazo que abarca la primera mitad del siglo XIX. Sin embargo, la guerra de castas ha

\footnotetext{
2 Sierra O'Reilly, 1954; Cline, 1947 (partes de la tesis de Cline fueron publicadas en forma de artículos, los cuales son más accesibles que la tesis, véase especialmente Cline, 1978: 3-23); Reed, 1970: 55-56; González Navarro, 1970: 63-67; Quintal Martín, 1976: 60-89; Bartolomé y Barabas, 1981; Bricker, 1993: 178-186; Lapointe, 1983; Bracamonte, 1993: 29-47; Rugeley, 1996; Patch, 1983: 17-26, 1990: 45-95.

${ }^{3}$ Véase, por ejemplo, Cline, 1950 (contiene un estudio titulado "The War of the Castes an its Consequences"); Reed, 1970; Bartolomé y Barabas, 1981; Lapointe, 1983. Una bibliografía más extensa al respecto puede verse en Quezada, Güémez y Tapia, 1986, especialmente pp. 76-85.
} 


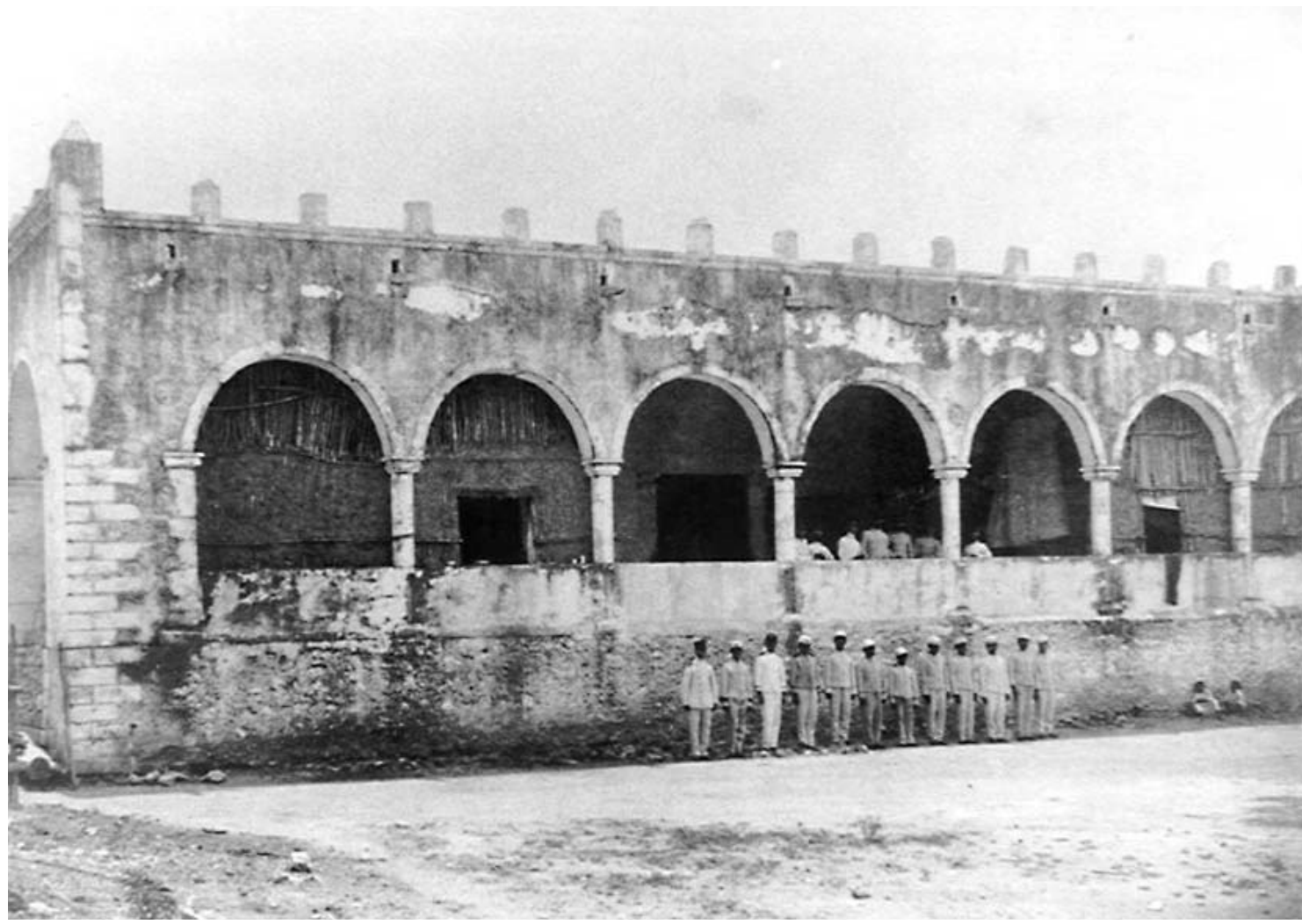

Hospital Ichmul. Guerra de castas, 1901 / Centro de Apoyo a la Investigación Histórica en Yucatán.

sido una cuestión insoslayable, y nuestros resultados nos permiten expresar una opinión propia en torno al problema de la privatización como factor de dicho conflicto.

\section{LUZY SOMBRA DEL LIBERALISMO AGRARIO YUCATECO (1812-1840)}

Yucatán, como otras regiones de México, sólo de nombre había formado parte de la Nueva España, es decir, del núcleo que giraba en torno a la ciudad de México y abarcaba los valles centrales que rodeaban la capital, la cuenca de Puebla hacia el este, las tierras altas de Michoacán hacia el oeste y también el Bajío y las zonas ganaderas y mineras de Zacatecas y San Luis Potosí. En este espacio, durante la Colonia, se había constituido y renovado constantemente una sólida oligarquía, a pesar del contrapeso que, en cierto modo, representaba el Estado al proteger a las comunidades indígenas.

Aunque la península yucateca fue gobernada por funcionarios españoles, durante toda la época colonial había recibido a pocos colonizadores hispanos y tuvo escasa participación en la economía de la masa colonial novohispana ${ }^{4}$ - lo mismo que en la guerra de independencia-. En Yucatán, como en casi todo el sureste, gran parte de la población indígena se había librado por mucho tiempo de una penetración española intensa gracias a la falta de plata y otros alicientes económicos en su suelo, pues, de hecho, diversos cultivos a los que estaban acostumbrados los migrantes españoles fueron infructuosos en él. Tampoco pudieron incursionar en la producción

\footnotetext{
${ }^{4}$ Tutino, 1990(b): 98-99.
} 
de maíz, porque era suficiente con la que aportaba la población indígena y de cuyo excedente vivían en gran medida los encomenderos. Finalmente lograron fomentar estancias ganaderas y, hacia mediados del siglo XVIII, consolidaron la hacienda ganadera milpera, aunque estas unidades productivas no rebasaron la región noroeste y otros escasos puntos de la península. ${ }^{5}$ Por ende, en Yucatán vivieron hasta el fin de la época colonial unos cuantos funcionarios y una élite colonial, que no llegaba a la opulencia, entre una mayoría de campesinos indígenas excepcionalmente autónoma. Existe, además, un grupo intermedio que fue formándose en el transcurso de la Colonia y que estaba ávido por invadir el sector productivo, en particular el ramo de la ganadería.

Es por ello que en Yucatán los postulados liberales hispánicos en boga a principios del siglo XIX, de dar movilización a las tierras ocupadas por las comunidades campesinas, con visos a obtener incrementos en la producción, y por tanto ventajas económicas, fueron bien vistos desde un principio, pero excluyendo la idea original de convertir a los campesinos en dueños de tierras. En Yucatán, a pesar de haberse publicado el decreto de las Cortes del 9 de noviembre de 1812, que abolía los servicios personales y las contribuciones especiales que pesaban sobre los indios y que disponía además el reparto de tierras del común a los mismos, la disposición sólo fue cumplida a medias — gracias a un triunfo de los sanjuanistas sobre el grupo rutinero o conservador- al dispensarse a los indios de los servicios personales y de las obvenciones que pagaban al clero. El logro de esa agrupación liberal tuvo efectos inesperados. En vista de su libertad, los indígenas propendieron de manera inmediata a dispersarse en los montes y arrancharse en ellos. En fin, una actitud que en nada estuvo, según los testimonios de la época, en llevar a la ruina a la élite de la provincia. Pero tal situación se fue atenuando hacia 1815 por efecto de la abolición en España de la Constitución de Cádiz $\mathrm{y}$ de sus respectivos decretos.

En cuanto a las tierras que mencionaba el decreto, independientemente de que los ostentantes del poder po-

${ }^{5} \mathrm{Al}$ respecto véase Patch, 1976: 21-61. lítico no llevaron a la práctica esa doctrina agraria, entre las expectativas de los campesinos indígenas yucatecos no se encontraba la de convertirse en propietarios de un terreno limitado o pequeño para producir y reproducirse como agricultor, fundamentalmente, por el sistema de cultivo practicado en Yucatán, que los hacía ser una especie de productores semierrantes. Sin que esto tenga forzosamente que decir que los indígenas no tuviesen ningún interés en constituirse en propietarios o que fueran "refractarios" a ese tipo de posesiones, pues desde la época colonial ${ }^{6} \mathrm{y}$ durante toda la primera mitad del siglo XIX, como nos ha tocado comprobar, había un importante núcleo de propietarios indígenas en el campo yucateco, cuyas posesiones imprimían dinamismo a un mercado de tierras del que se beneficiaban los grupos criollos y mestizos. $^{7}$

Sin embargo, dada la calidad del suelo de la península, la única forma de hacer cultivable un terreno era con el sistema de roza; la tierra no se abonaba, ni era factible el uso del arado y tampoco se poseían sistemas de riego, por lo que todos los terrenos eran de temporal. Con este sistema de cultivo, los labradores se veían obligados a sembrar en un mismo año dos terrenos al mismo tiempo, es decir, a hacer dos milpas. Una de ellas la hacían en un terreno con monte nuevo o, mejor dicho, con arboleda crecida para derribarla y quemarla y proceder luego a la siembra sobre sus cenizas. A esta milpa se le denominaba milpa roza. La otra, conocida como milpa caña, se hacía con la quema de los rastrojos de las plantas de maíz de la cosecha anterior. Con tal sistema, un terreno nunca era utilizado tres años consecutivos ni nunca en un mismo año sembrado en dos épocas distintas. Un terreno que ya había sido utilizado tanto para la milpa roza como para la milpa caña no se volvía a cultivar, sino hasta después de 12015 años, cuando ya tuviese una nueva vegetación propia para iniciar un nuevo ciclo de cultivo. De ese mo-

\footnotetext{
${ }^{6}$ Sobre este periodo véase Bracamonte y Solís, 1996, especialmente el capítulo 3 .

7 En el Archivo Notarial del Estado de Yucatán se hallan numerosos documentos de la primera mitad del siglo XIX que dan cuenta de las transacciones de compra-venta efectuadas entre indígenas e individuos de los grupos criollos y mestizos.
} 
do, el sistema de cultivo itinerante practicado en Yucatán, en el mejor de los casos, exigía 12 o 15 tantos más de superficie territorial del que se requería con una agricultura sedentaria.

Pero si la agricultura peninsular era incompatible con propiedades cuya extensión no satisficiera las exigencias del sistema de cultivo, en el campo yucateco había otro factor problemático: la práctica del libre pastoreo de los criadores de ganado, que fue la fuente principal de continuos enfrentamientos. El problema, desde luego, no era nuevo, puesto que desde fines del siglo XVI hubo una relativa expansión de las estancias ganaderas no sólo particulares, sino también corporativas, las correspondientes a las cofradías. Sin embargo, hasta fines de la Colonia ese problema no parecía ser algo que causase aversión a los usufructuarios de las tierras comunales; la ganadería de los particulares como la de las cofradías era bastante modesta. Con la irrupción de las ideas liberales agrarias consolidadas en el decreto del 4 de enero de 1813, que dispuso la reducción a propiedad particular de todos los terrenos (comunes y realengos), excepto los ejidos de los pueblos (500 varas, 600 varas, una legua según diversas leyes coloniales), impulsaron las pretensiones de un nutrido grupo medianamente pudiente cuya intención era incursionar en la cría de ganado; esto, desde la primera época del constitucionalismo español y nuevamente con la vuelta al constitucionalismo en 1820 . Cabe destacar que dicho proceso desamortizador contó con el importante apoyo de los ayuntamientos — cuya proliferación en la mayoría de los pueblos fue propiciada también por disposiciones de la Constitución de Cádiz—, dado que eran los directamente beneficiados con el producto de las ventas.

La demanda de tierras exasperó a los labradores de los pueblos, la mayoría de los cuales durante toda la época colonial había estado exenta de la indeseable presencia del ganado. Empero, la tenaz resistencia de los pueblos mostrada durante la vigencia del decreto de 1813, aunada a la nutrida afluencia de ideas fisiocráticas ${ }^{8}$ divulgadas

\footnotetext{
${ }^{8}$ Éstas propugnaban por la prioridad de la agricultura en las sociedades por ser la única actividad, según sus postulados, que proporcionaba producto neto y consideraba a todas las demás como actividades secundarias o estériles.
}

por el periódico oficial del Congreso local, permearon parcialmente en la época independiente la ley de colonización que la legislatura del estado emitió en 1825, y en la que se dispuso la concesión de terrenos, pero con rigurosas restricciones. No obstante, ni esta nueva ley, ni un decreto aclaratorio de 1827 —que impuso severas restricciones a la cría de ganado, precisamente por abusos y frau$\operatorname{des}^{9}$ cometidos por quienes obtuvieron concesiones de terrenos al calor de la ley de colonización — pudieron frenar el ímpetu de este grupo pro ganadero. Éste, luchando contra la adversidad, impulsó primero un proyecto para regularizar a los criadores establecidos sin título de propiedad en los terrenos baldíos, truncado por el advenimiento al poder de un grupo pro centralista en 1829. El nuevo gobierno, emanado de un golpe militar, en cuyas filas debió encontrarse una poderosa fracción de antiguos hacendados, también puso de su parte con un nuevo aclaratorio, decretado el 26 de julio de 1831, orientado no sólo a restringir aún más las concesiones para la cría de ganado, sino también para contrarrestar el arranchamiento de los indígenas reduciéndolos a vivir en poblados reconocidos por la ley y prohibir la labranza sin cerco en lugares que no distaran por lo menos de cuatro leguas de las haciendas establecidas. Al calor de tal disposición se cometieron diversos abusos.

El gobierno pro centralista se inclinó hacia una acción jurídica con marcada tendencia a proteger a los antiguos hacendados, ${ }^{10}$ tanto del grupo pro ganadero ${ }^{11}$ como del partido con propensiones de dispersión de la población indígena. Sin embargo, tales acciones no pudieron ser llevadas más a fondo, como sin duda se pretendía, por

\footnotetext{
${ }^{9}$ La ley de colonización exigía a los solicitantes haber ocupado los terrenos por espacio de cuatro años "sin contradicción", es decir, sin problemas, además de que sólo se les concedería el espacio que hubiesen fomentado. Los fraudes consistieron en la presentación de documentos falsos que avalaban el cumplimiento de tales requisitos.

${ }^{10}$ Denominamos así, o simplemente hacendados, a aquéllos cuyas propiedades, por lo común de gran extensión, tuvieron su origen en la época colonial y se hallaban consolidados en el campo yucateco mediante actividades en el ramo ganadero y con tierras de arriendo destinadas a la agricultura.

${ }^{11}$ Identificamos como grupo pro ganadero a aquéllos que, alentados por las leyes liberales, tendieron a la obtención de tierras, por lo general de poca extensión, para el fomento de la ganadería de libre pastoreo.
} 
una nueva irrupción de los federalistas en noviembre de 1832. Con el retorno de estos últimos, un proyecto que puso al descubierto la depredación ecológica que los agricultores causaban en una amplia zona del partido de la Costa, que aunado con la "ayuda" del cólera, demostró la vulnerabilidad de la agricultura ${ }^{12} \mathrm{y}$, por supuesto, de los agricultores, con lo que obtuvieron un efímero triunfo con la ley reglamentaria para la venta de terrenos baldíos de 1833, que correspondía plenamente a sus intereses.

Hasta entonces no se había advertido la profunda aversión a la propensión ganadera de otro grupo que, aunque minoritario, era el más poderoso de la península, es decir, los hacendados. A éstos, si bien no estaban marginados de los grupos políticos del estado, la fuerte corriente liberal predominante, que prácticamente había monopolizado el poder - excepto en el breve lapso dominado por los militares pro centralistas (1829-1832), en el que comenzaron a bosquejarse las pretensiones de los antiguos hacendados - no les había permitido una acción contundente, aunque es probable que esta situación, a pesar de la competencia, no les resultaba tan apremiante y que muchos de ellos habían sumado la vía liberal a sus antiguos métodos para obtener los terrenos que requiriesen. En fin, ni los pro ganaderos ni los antiguos hacendados o, mejor dicho, los "partidos" políticos que tendieron a apoyarlos, tuvieron la longevidad suficiente para desarrollar sus pretensiones respecto a los grupos con los que disputaban los espacios territoriales. Huelga decir que ante las pretensiones de ambos, al grupo mayoritario representado por las comunidades indígenas sólo le quedaba la opción de adoptar, por las vías que fuesen necesarias, una férrea resistencia para no perder las tierras de usufructo comunitario.

La formación de ranchos de manera "furtiva" ocupó un lugar prominente en esa resistencia, amén de las constantes denuncias de carácter legal contra todo aquel que pretendía violentar los espacios de tradicional usufructo comunal, sin importar si lo hacían con el apoyo de las leyes o sin ellas, como nunca lo habían dejado de hacer

12 Uno de los más sensibles efectos de esta epidemia es que apenas se logró un $10 \%$ de los cultivos.

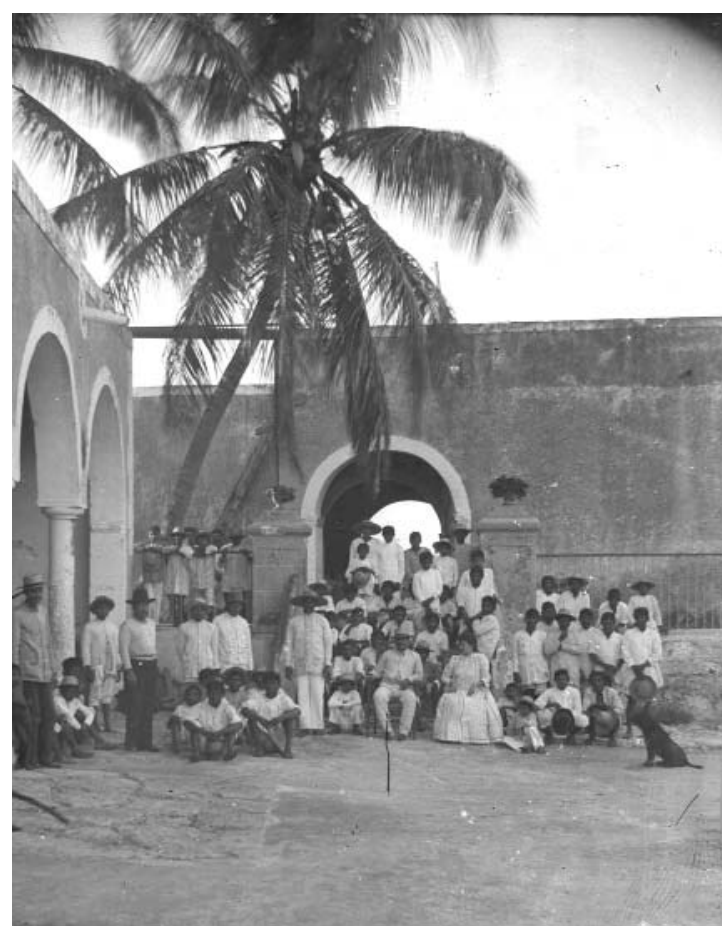

Hacienda henequenera, 1920 / Fototeca Pedro Guerra, Universidad Autónoma de Yucatán.

diversos hacendados y cortadores de maderas. Habría que recalcar que las condiciones que erigían a los comuneros indígenas como "eternos contradictores" era la imprecisión de los límites no sólo de sus ejidos y terrenos comunes, sino de los antiguos terrenos realengos, ahora llamados baldíos, e inclusive los de muchos de los llamados particulares. En fin, ese "inextricable laberinto" fue la condición fundamental que permitió la tenaz resistencia indígena, pues a fin de cuentas ellos, con o sin títulos, se sentían dueños de las tierras que no estuviesen perfectamente definidas como propiedad particular.

Si se hubiese hecho una formal alianza contra la ley reglamentaria (pro ganadera) de 1833, sus tres fracciones estarían formadas, en primer lugar, por los indígenas como usufructuarios mayoritarios de las tierras; en segundo, por los labradores en grande o "gruesos", como se autodenominaban quienes empleando mano de obra pagada hacían sus sementeras en terrenos reputados como realengos o baldíos — como los calificaba la legislación 
republicana—; y por último, los hacendados, dedicados prioritariamente a la ganadería de libre pastoreo. Pero la reacción vino por separado y cada una a su tiempo. Ambos grupos de labradores, o mejor dicho, la actividad que practicaban, la agricultura, fue defendida con ahínco en el momento de la promulgación de la ley en representaciones de las corporaciones municipales - desde la emisión de la ley de colonización de 1825, que las marginó de los ingresos de la enajenación de tierras, con cierta frecuencia brindaban su apoyo a las comunidades indígenas-, las que promulgaban las grandes ventajas que ofrecía la agricultura en comparación con la ganadería, así como la nocividad del libre pastoreo del ganado para las sementeras que se hacían sin cerco.

Los hacendados tuvieron su turno con relativa prontitud gracias a la nueva irrupción del grupo políticomilitar que abogaba por el centralismo. Asimismo, la prolongada secuela del cólera había cambiado mucho el panorama rural yucateco, sobre todo por la inusitada dispersión de la diezmada población indígena. El régimen centralista tendió de manera abierta a beneficiarlos con amparo debió llegar tangencialmente al común de los labradores, los hechos (a raíz de la promulgación del decreto del 27 de junio de 1827, orientado a combatir el abigeato) nos demuestran contundentemente que la lucha de los hacendados y sus aliados gubernamentales fue principalmente contra el modo de vida que había asumido gran parte de la población indígena, es decir, contra su propensión a la formación de ranchos furtivos en los montes. La oligarquía y la élite política no dudaban en señalar lo anterior como la principal causa de ese delito y al mismo tiempo de la despoblación de los pueblos y los establecimientos reconocidos por la ley, así como de la evasión de contribuciones civiles y eclesiásticas.

Sin embargo, aquel ataque también iba dirigido contra aquellos que practicaban la ganadería en pequeña escala en terrenos que no cumplían con los requisitos que las leyes anteriores a la de 1833 exigían. No fue nada fortuito el que el gobierno centralista anulara esta última y reactivara la ley de colonización de 1825 y sus correspondientes aclaratorios de 1827 y 1831, ya que sus cláusulas encerraban un marcado proteccionismo tanto para las

haciendas establecidas como para las sementeras de los labradores que se hacían sin cerco. Esto no era perceptible en la ley reglamentaria de 1833 , pues era precisamente el resultado de un proyecto cuya finalidad consistía en promover la venta de terrenos a todo individuo que lo solicitase y en regularizar las distintas posesiones para el fomento de la ganadería. Esta ley tuvo su origen en un proyecto para colonizar un espacio de tradicional usufructo comunal por parte de diversos pueblos del partido de la Costa, pero alcanzó en ella un carácter general para atender las solicitudes de terrenos de toda la península.

Si bien la rehabilitación de la ley de colonización de 1825 y de sus decretos aclaratorios de 1827 y 1831 fue llevada a cabo en aras de corresponder a los hacendados, todo parece indicar que el gobierno intentó ser más benévolo con ellos a través de una nueva ley de colonización decretada el 4 de abril de 1837. Las evidencias existentes de esta ley, pero sobre todo unas extrañas concesiones que les otorgó para que mensurasen los supuestos límites de sus territorios, no dejan lugar a dudas. Sin embargo, los hacendados abusaron de las prerrogativas centralistas y el mismo gobierno se vio obligado a poner un freno a sus desmedidas pretensiones sobre las tierras de los pueblos, lo cual demuestra que este último no había perdido del todo la prudencia. Ante los ojos de los pueblos, esto no dejaba de ser una muestra de debilidad o de que la alianza gobierno-hacendados no era lo suficientemente sólida para proceder a un despojo masivo. A pesar de ello, las diversas acciones que dieron frutos, inclusive inesperados, como la destrucción de sitios de ganado y muchas de los actos cometidos para reducir a los indígenas a poblado constituyeron, no obstante a su relatividad, éxitos inobjetables para los hacendados.

Se puede decir que de 1812 a 1840 el proceso de adopción o adaptación de las ideas liberales en torno a la posesión de la tierra - aunque no influyó directamente o por su propio peso en las convulsiones políticas de la élite- sí mantuvo estrecha dependencia con los intereses de la clientela política de los grupos que ascendían al poder. De tal modo, que aquel sagrado derecho de todos los individuos a la propiedad, pragmatizado por los liberales yucatecos para beneficio de un grupo medianopudiente pro ganadero y para subsanar las carencias del 
erario de los municipios y del estado, paradójicamente, durante el centralismo fue reducido a la protección del "sagrado derecho" de propiedad de los hacendados. ${ }^{13}$

El centralismo pro oligárquico llegó a su fin en los albores de 1840 al ser derrocado por el grupo que estaba en el poder en 1834. ¿Cuál fue entonces el rumbo de la política agraria en los años subsiguientes frente a unos pueblos con territorios comunales todavía sólidos y frente a los intereses de los distintos grupos que pretendían la posesión de la tierra?

\section{LA LEY DE COLONIZACIÓN DE I84I: CRÓNICA DE UN FRACASO}

El carrusel político yucateco no parecía tener descanso. El centralismo en Yucatán llegó a su fin en los albores de 1840. Había causado malestar en gran parte de la población: a los indígenas por la tenaz persecución emprendida para contrarrestar su dispersión y reducirlos a vivir en poblados reconocidos por la ley, a los pobladores en general por el forzoso reclutamiento para el servicio de las armas en la lucha contra los texanos, a las comunidades labradoras por los diversos atentados contra sus tierras. La economía de los yucatecos se había afectado también por diversas leyes hacendarias expedidas con la finalidad de afrontar los gastos que demandaba la guerra que mantenía el gobierno mexicano contra los colonos de Texas y algunas de las cuales dañaban ciertos privilegios que gozaba la península a raíz de su inserción al sistema federal. ${ }^{14}$ La privación de una parte considerable de sus

13 Sobre el proceso desamortizador referido, véase de manera extensa y documentada en Güémez Pineda, 1994. En este trabajo se intentó mostrar el difícil camino que tuvo que recorrer la adopción y adaptación de los postulados liberales en materia agraria en una sociedad con la fuerte presencia de comunidades indígenas, cuerpos característicos del antiguo régimen colonial. El detectar la irrupción de un grupo social intermedio como un actor que resquebraja la antigua dicotomía hacendados-comunidades en la lucha por la tierra, permite observar una interpretación distinta a la que ve al liberalismo como una ideología que llegó para fortalecer de manera exclusiva las perspectivas expansionistas de los hacendados.

14 Por ejemplo, los puertos de la península disfrutaban desde 1827 el privilegio de no pagar más que las tres quintas partes de los derechos aduanales que se pagaban en otros puntos más ricos de la República, rentas creó animadversión, inclusive entre los partidarios del régimen centralista, pero poco o nada pudieron hacer las autoridades de la península para mejorar la situación. Esto fue capitalizado por los federalistas, quienes no habían dejado de movilizarse y contaban con prosélitos en los ayuntamientos, en los tribunales y aun en la misma Junta Departamental centralista. El levantamiento armado era prácticamente inevitable; después de intentos infructuosos del capitán Santiago Imán en el oriente de la península, éste llamó a sus filas a los indios de la zona con la oferta de abolir las obvenciones que pesaban sobre ellos, ${ }^{15}$ lo cual produjo un efecto "maravilloso", pues éstos estaban dispuestos a cualquier sacrificio para librarse de esa contribución.

Para mediados de febrero de 1840 , los pronunciados habían tomado Valladolid, la población más importante del oriente, y levantaron un acta de varios artículos, entre los cuales se declaraba que se restablecería la Constitución de 1825; que serían reinstaladas todas las autoridades derrocadas en 1834; que el Congreso, con carácter exclusivamente convocante, dispondría la realización de las elecciones para la renovación de los funcionarios y que, dado que la capital todavía se encontraba en manos de los centralistas, lo cual impedía que los diputados y el gobernador entrasen inmediatamente en función, se establecería interinamente una Junta Gubernativa, misma que estuvo compuesta por Pablo Castellanos, Agustín Acereto, Miguel Cámara y los curas Buenaventura Pérez y José Antonio García. En cuanto a la promesa a los indios, se declaró que las obvenciones que pagaban las mujeres indígenas quedarían abolidas y que todo varón contribuiría con un real mensual que debía pagar a su párroco.

El movimiento fue secundado en Mérida por militares y por un nutrido grupo de simpatizantes del partido federalista, quienes levantaron un acta similar al de Valladolid, pero explicitando la derogación de todas las disposi-

\footnotetext{
pero a partir de 1837 se les impuso la obligación de pagar íntegros tales derechos, amén de que por efecto de diversas leyes también se impuso a Yucatán la obligación de remitir a México el 17, 15, 12, 10 y 8\% del producto de sus aduanas.

${ }^{15}$ Este impuesto consistía en veintiún reales y medio que anualmente pagaba al clero todo matrimonio indio, correspondiendo doce reales y medio al varón y nueve a la mujer.
} 


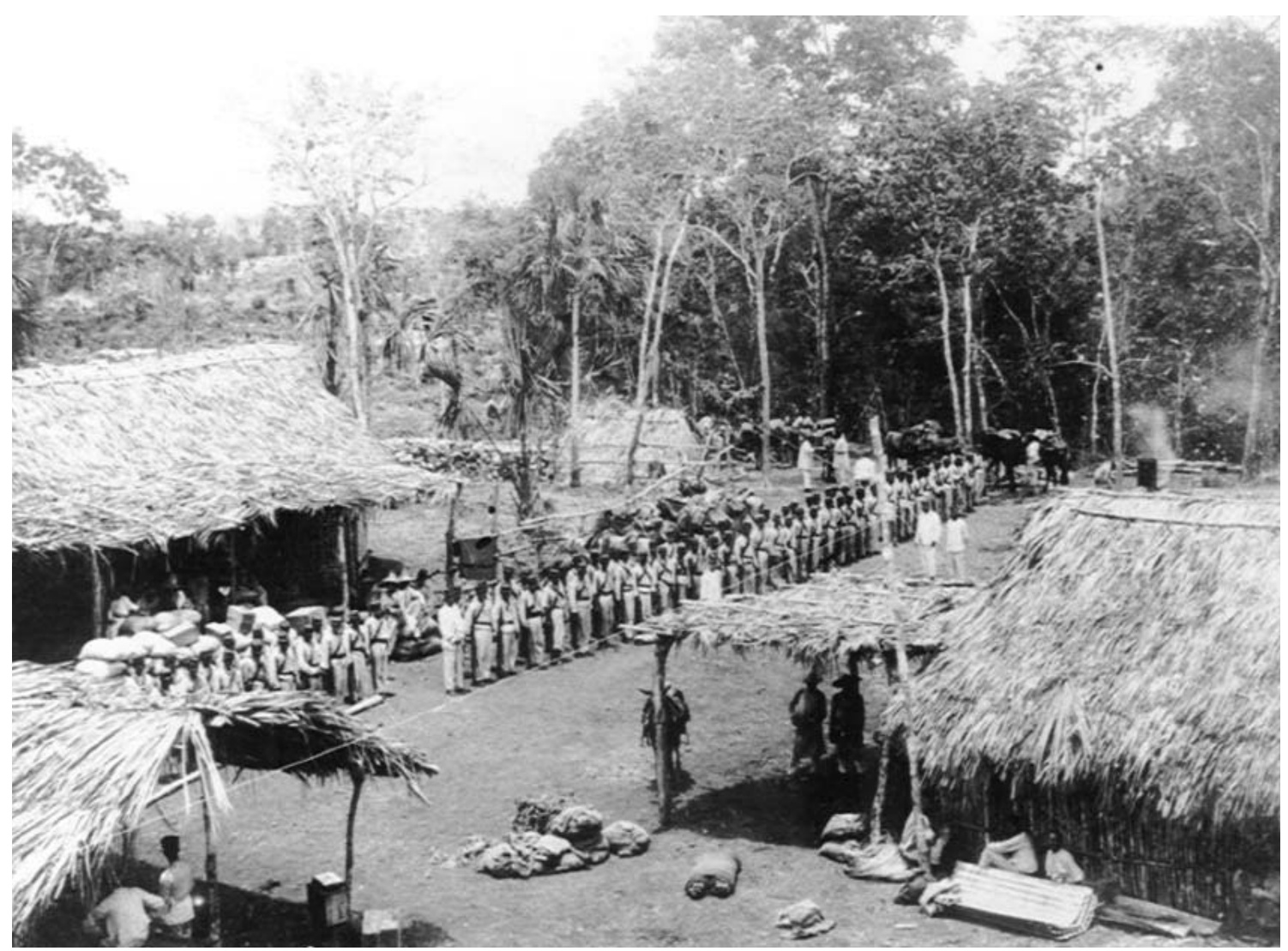

Cuartel y guarnición general en la guerra de castas. Nohpop, 1901 / Centro de Apoyo a la Investigación Histórica en Yucatán.

ciones emanadas del gobierno centralista y la separación de Yucatán, hasta que en México volviese a adoptarse el sistema federal. Al terminar el mes de febrero, la sublevación era generalizada y sólo quedaba en poder de los centralistas la plaza de Campeche, en la cual, como producto de algunos enfrentamientos y del sitio impuesto a esa ciudad, capitularon, a mediados de junio, las huestes del general Rivas Zayas y las tropas que vinieron de Veracruz en su apoyo.

La restablecida legislatura abrió sus sesiones el 28 de febrero de 1841. El 4 de marzo expidió un decreto que resumía los deseos expresados en las actas de pronunciamiento, declaraba restablecidas tanto la Constitución del Estado de 1825 como la de la República de 1824, así como todas las leyes vigentes antes del golpe centralista. Asimismo, declaró que mientras las instituciones federales no fuesen restablecidas en la República Mexicana, Yucatán permanecería separado de ella. Entre otras disposiciones mandó efectuar las elecciones de los poderes públicos, decretó el 29 de abril la exoneración del pago de obvenciones de las mujeres indígenas y el pago de doce reales anuales por parte de los varones y finalmente cerró sus sesiones el 4 de mayo. La Junta Gubernativa cesó en sus funciones luego que se hizo cargo del gobierno Juan de Dios Cosgaya, el gobernador derrocado en 1834, quien a su vez cedió el puesto a Santiago Méndez, ${ }^{16}$ ganador de

${ }^{16}$ Méndez había sido en su juventud camarillero, es decir, miembro del grupo opositor que ahora regresaba al poder. Contaba a su favor con antecedentes que afirmaban su convicción por las instituciones del grupo que ahora lo había apoyado, entre ellos el de haberse opuesto al golpe promovido por Francisco Toro en 1834, que desembocó en 
las elecciones. El cargo de vicegobernador recayó en Miguel Barbachano, quien hacía su primera aparición en la escena política yucateca.

Mientras todo aquello sucedía en Yucatán, el gobierno central de México, presidido por Bustamante, expidió decretos en los que "cerraba" los puertos de Sisal y Campeche y declaraba que los buques yucatecos debían ser considerados piratas por las "naciones amigas de la República". ${ }^{17}$ Por su parte, la legislatura constituyente, que había abierto sus sesiones en agosto de 1840, se había ocupado de reformar la Constitución de 1825. Para tal fin nombró una comisión especial presidida por Manuel Crescencio Rejón, la cual presentó su proyecto el 23 de diciembre de 1840 , en el que ocupaba un lugar sobresaliente la reforma religiosa. Los periódicos habían venido emitiendo opiniones sobre las relaciones entre la Iglesia y el Estado. Las comunicaciones entre ambas autoridades respecto a las restricciones con las que el obispo Guerra había jurado las leyes federales y la supresión de las obvenciones que pagaban las mujeres había originado un gran número de artículos en los que "se condenaba las demasías del clero y se les excitaba a imitar la humildad y pobreza del fundador del cristianismo". La comisión, haciendo eco de tales ideas, propuso la libertad religiosa, la abolición de toda clase de fueros y la extinción del privilegio que tenía el clero para aplicar penas temporales. Destacaban otras dos propuestas, una que pretendía poner un contrapeso al poder del gobernador, asociándolo con dos cónsules, y otra que planteaba la elección popular y directa de los miembros de los poderes ejecutivo y legislativo. El proyecto contenía otras reformas administrativas que no alteraban sustancialmente el régimen establecido en la Constitución de 1825 .

Luego de tres meses de discusión, la asamblea adoptó todas las reformas propuestas, con excepción de la relativa a los cónsules. El nuevo código fue finalmente expedido

la instauración del centralismo en Yucatán, amén de que desempeñó un papel clave en el triunfo de los federalistas.

17 Si bien la primera no tuvo consecuencias; la segunda sí, pues dio la pauta para que el gobierno de la colonia inglesa de Belice pudiese amenazar y exigir al gobierno yucateco una indemnización por concepto de la goleta True Blue, confiscada en playas yucatecas al intentar introducir efectos de contrabando. el 31 de marzo de $1841 .^{18}$ Pero lo que aquí nos interesa destacar, en primera instancia, es que el grupo que había ascendido al poder se había declarado abiertamente antioligárquico. A través de los periódicos, especialmente del periódico Los Pueblos, emprendió un ataque contra el centralismo y sus partidarios. En un editorial afirmaba que "seis años de un penoso sufrimiento había prometido a la oligarquía el triunfo completo de sus miras parricidas, creyendo que su poder y siete leyes constitucionales, gozando del beneficio de la prescripción, habían de ser para siempre la norma de todos los estados..."19 En alusión al general Rivas Zayas que se encontraba encerrado con su guarnición en Campeche, única plaza que quedaba en poder de los centralistas, otro editorial apuntaba: "La causa que sostiene el Sr. Rivas es la de una facción, que con el mayor descaro aspira a tiranizar la República, es la de la oligarquía que procura el engrandecimiento de ciertas clases con la ruina de los intereses de la comunidad, es la del oscurantismo y retroceso que tiende a sofocar las innovaciones del presente siglo y desatender a sus exigencias..." 20

Aquel espíritu antioligárquico sin duda emanaba de los agravios que había sufrido la mayoría de la población durante el centralismo, sin embargo, los hechos posteriores, en particular los relativos a la cuestión agraria, nos demuestran que uno de los principales malestares que había ocasionado el centralismo era la restricción del proyecto liberal que, antes de la irrupción centralista, había tendido a beneficiar a la clase media yucateca mediante la enajenación de terrenos en su favor para el fomento de la ganadería. Es por eso que en el momento del ascenso de los federalistas al poder, afloró en editoriales la necesidad de reactivar por medio de las leyes dicho proyecto, aunque esta vez con la firme intención de atraer capitalistas nacionales y extranjeros, a fin de que las tierras que se colonizaran se destinasen al fomento de la agricultura. En ese sentido, el periódico Los Pueblos señalaba en octubre de 1840:

\footnotetext{
18 Sobre los acontecimientos políticos y militares referidos, véase Ancona, 1879 , t. III, pp. 358-396.

${ }^{19}$ Los Pueblos, Mérida, 7 de abril de 1840.

${ }^{20}$ Los Pueblos, Mérida, 18 de abril de 1840.
} 
¡Cuánto interesa una buena y bien meditada ley de colonización! Si a los habitantes de nuestro Estado, a los nacionales y a los extranjeros se les diese el dominio útil de los feracísimos terrenos que se hallan en la parte oriental de esta península, los que se encuentran en las márgenes del Río Hondo y en otras muchas partes, ¿cuánto bien no resultaría a la agricultura? Nuestra población se aumentaría en razón directa de la utilidad y ventajas que prestase a los colonos el legislador. De todas partes vendrían gentes a fertilizar esos campos de donde no se saca el menor provecho. Los capitalistas, contando con las garantías de la ley, emprenderían sus negociaciones agrícolas en grande, y los terrenos serían por este solo medio, un manantial seguro e inagotable de riqueza pública. ${ }^{21}$

Por su parte, un editorial del periódico El Siglo XIX afirmaba en diciembre de 1840 que era incuestionable el hecho de que Yucatán fuera "susceptible de grandes mejoras y de adelantos materiales, principalmente en el riquísimo y variado ramo de la agricultura", pero no dejaba de apuntar un gran problema para ello, que consistía en la falta de brazos trabajadores lo que impedía la explotación y perfeccionamiento de la agricultura, la cual consideraba una "abundante e inagotable mina". Recordaba cuántos establecimientos o rancherías plantados en tierras feraces habían quedado paralizados por falta de brazos o no estaban satisfaciendo las expectativas de los empresarios por este mismo inconveniente. Convencido de la productividad del suelo yucateco y de que el trabajo es la fuente y origen de toda riqueza pública se cuestionaba si proveyendo a la península de brazos trabajadores se podría adquirir riquezas y felicidad y en poco tiempo variar la faz de Yucatán.

Mas estos brazos — continuaba el editorialista — indispensables para la creación y fomento de la agricultura y de la industria, tenemos necesidad de buscarlos fuera de nuestra patria, porque desgraciadamente nuestros indígenas son poco laboriosos y apenas bastan al cultivo del maíz y a la mezquina producción con que contamos. Brindar a trabajadores extranjeros y a hombres laboriosos a que vengan a cultivar nuestros campos, a enseñarnos a ser industriosos y económicos, es lo que importa al aumento de nuestra riqueza pública y al desarrollo de los elementos de pros-

${ }^{21}$ Los Pueblos, Mérida, 4 de octubre de 1840. peridad y grandeza que encierra nuestro suelo. Pero no bastan la intención y los buenos deseos para que las gentes trabajadoras de otros países aborden a nuestras playas, es menester que un gobierno protector y civilizado les otorgue las garantías de seguridad individual y de propiedad, y las franquicias correspondientes al libre ejercicio de su industria: es menester aún más que el país les acuerde la absoluta libertad de sus conciencias para que puedan tributar al creador pública y privadamente el culto que profesan. De este modo veríamos millares de brazos venir a labrar nuestras tierras, a perfeccionar nuestra industria, a crear y fomentar medios de riqueza pública; y el aspecto de Yucatán de lánguido y miserable en que se halla, tornaría a robusto, floreciente y envidiable... ${ }^{22}$

Antes de legislar sobre la enajenación de tierras que implicaban aquellas propuestas, la legislatura, por conducto del gobierno, hizo circular a mediados de febrero de 1841 una orden para que las corporaciones municipales informaran sobre la conveniencia o perjuicios que produciría la venta de terrenos del Estado. Tenemos dos respuestas a esa circular que sin duda sintetizan la visión del problema por parte de los pueblos. Una de ellas provino del ayuntamiento de Campeche, quien en vista de la elaboración de su informe nombró una comisión para "explorar la opinión" de las repúblicas de indígenas de sus barrios y de "algunos vecinos dignos de consideración por sus luces y conocimientos". Las opiniones de los miembros de dicha comisión estuvieron divididas, es decir, unos apoyaban la venta de tierras con ciertas restricciones, como la de respetar los ejidos y los fundos legales de los pueblos y preferir el sistema de la pequeña propiedad que el de la grande, pero otros rechazaron tajantemente dicho proyecto.

Ante tal perspectiva, Pantaleón Barrera, secretario del ayuntamiento, argumentó en su informe al gobierno que si bien las sugerencias de los que apoyaban el proyecto podían ser muy convenientes, en otras circunstancias, no podían ser aplicadas en Yucatán, donde, ya sea la grande o pequeña propiedad, no dejaría de ser perjudicial a la clase menesterosa del estado. Porque aunque se proponía el respeto al fundo legal de los pueblos, tales tierras

${ }^{22}$ El Siglo XIX, Mérida, 4 de diciembre de 1840. 


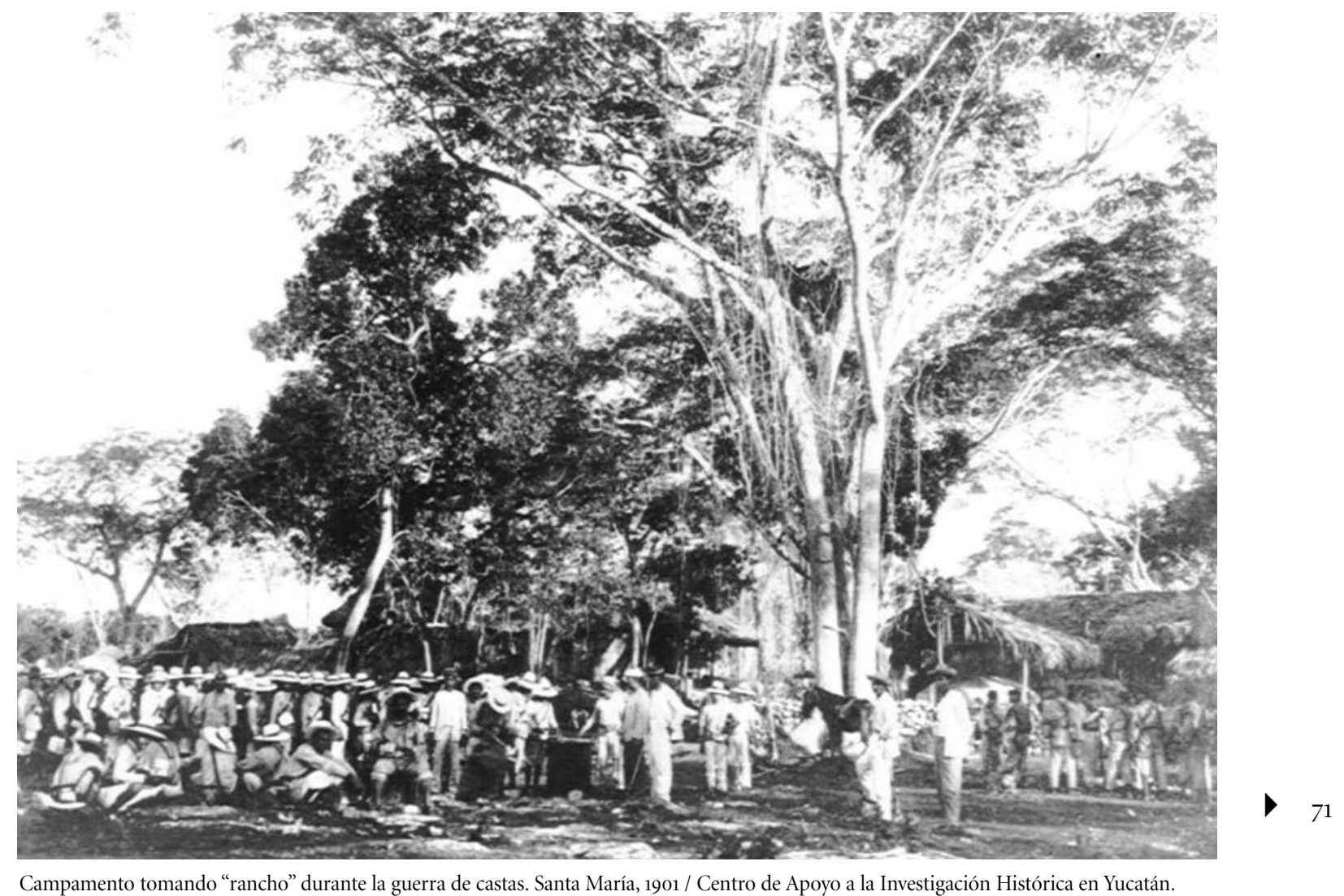

no existían en algunos de ellos o su extensión era demasiado corta, o simplemente no eran propias para sus siembras por falta de conocimientos o de los instrumentos necesarios para hacerlas cultivables. En suma, tales terrenos no eran suficientes para los comuneros que, en su mayor parte — decía Barrera-eran pobres y de escasos recursos para adjudicarse la más pequeña propiedad en los terrenos que pondría en venta el gobierno. Venta de la que resultaría o "un gran número de ociosos reducidos a la más triste indigencia u otros tantos esclavos dependientes de los propietarios", extremos que no dejaban de ser dolorosos. Barrera apuntaba que no podía hallar un término medio a esas situaciones, pues mientras no se procurara regularizar la agricultura mediante la enseñanza, mientras no se consiguiera la "civilización e instrucción" de los indígenas, no se podía hacer ninguna innovación importante. Por lo tanto, concluía que no era convenien- te hacer ninguna innovación en el uso y aprovechamiento de los terrenos del Estado. ${ }^{23}$

Otro informe, proveniente de la junta municipal de Chancenote, distingue primero tres tipos de terrenos en función de su ocupación: 1) los que se encontraban ocupados sin títulos de propiedad, es decir, por "meras posesiones" de cierta importancia agrícola o de cría de ganado, así como por aquellos que sí poseían dicho título; 2) los que estando a disposición de los labradores no estaban ocupados por ellos; 3) los que se encontraban fuera del contacto con los labradores del estado y se denominan "inaccesibles o colonizables". Respecto a los agricultores de la península distinguía a dos tipos, unos que eran fijos o radicados en sus labranzas, es decir, que te-

\footnotetext{
${ }^{23}$ El Siglo XIX, Mérida, 2 de marzo de 1841.
} 
nían establecimientos con más o menos mejoras, que eran muy pocos, y otros, que conformaban la mayoría de los agricultores, que labraban los campos de un modo "frágil y transitorio", pero que eran los que verdaderamente habían sostenido y sostenían al estado en sus necesidades más elementales. Asimismo, enfatizaba al sistema rotativo de los cultivos que se practicaba en la península como un inconveniente de primer orden para llevar a efecto la venta de terrenos, más aún si se atendía a que la mayor parte de las tierras de la península no eran suficientemente fértiles.

Con semejante sistema de cultivo, los labradores del estado - afirmaba la junta de Chancenote - que contaban con un derecho de posesión que les permitía todas las mejoras de arte y los usufructos consiguientes, no podían ser dueños del terreno, pero sí de sus mejoras, y éstas, cuando llegaban a ser importantes, se podían equiparar a las ventajas que proporcionaba el derecho de propiedad, pero sin los inconvenientes que éste acarreaba a las masas de las poblaciones. El derecho de propiedad en materia agraria — proseguía la junta — no había sido más que una prohibición de acceso a los recursos para la muchedumbre que una protección a sus goces, todo a cambio de un pequeño ingreso al Tesoro público. Además — apuntaba-, los terrenos sobre los que recaía el derecho de propiedad no correspondían a las facultades económicas de sus poseedores para labrarlos y eran inútiles a las masas, salvo en caso de legal o arbitrario arrendamiento. La junta también enfatizaba que ningún resultado favorable a los progresos de la agricultura había presentado el derecho de propiedad, como prueba indicaba que en partidos como los de Tizimín y de la Costa había haciendas de ganado - única forma de propiedad agraria que se conocía, además de las fincas urbanas ubicadas en los límites de las ciudades y de los pueblos grandesen las que nunca se había intentado la agricultura, y lo mismo ocurría en aquellos terrenos que habiendo sido en otros tiempos haciendas de propiedad particular, ya no eran más que terrenos yermos abandonados, aun cuando todavía contaban con la prerrogativa de propiedad particular.

La junta consideraba que no solamente por esos motivos se debía preferir el derecho de posesión al de pro- piedad, sino porque las dos "clases" (es decir, los ricos y los de medianas facultades, que podían adquirir los terrenos) estaban lejos de ser los que cumpliesen el objetivo de fomentar la agricultura. Amén de que de efectuarse las ventas de tierra nada faltaría a los poderosos para poner en práctica el monopolio en ese asunto de interés general, lo cual —indicaba - es reprobado en los pueblos cultos y tenido como un monstruo que absorbe los bienes de los que todos debieran participar.

La junta de Chancenote señalaba que los labradores de la península que ocupaban terrenos aportaban al Tesoro público sus cuotas de arrendamiento y que sus posesiones no eran perjudiciales para ningún otro agricultor fuera éste rico, de facultades medias o menesterosas, y sugería que tal producto por ese concepto podía ser mayor si se sistematizara mejor el cobro de esas cuotas. Por lo tanto, no dudaba en señalar que el monto total de esos arrendamientos, después de algunos años, correspondería al de la venta de los terrenos, con la ventaja de que "quedaría el manantial inagotable y disponible en urgencias de gran peligro".

Si bien la junta de Chancenote se oponía terminantemente a la enajenación de los terrenos que estaban ocupados por los agricultores, rechazaba de igual modo que se enajenaran aquellos cercanos y desocupados, porque, dado el sistema rotativo de cultivo, constituían una reserva para reponer las bajas que representaban los terrenos que después de cultivados quedaban agotados. También objetaba vigorosamente la venta de las posesiones agrícolas, pues sus ocupantes serían sacrificados al verse precisados a comprar el terreno en que hubiesen hecho mejoras, acaso por un costo igual al que éstas les costaron, amén de que la mayoría de ellos estaban desposeídos de recursos para impedir que otro interesado los perjudicara con la compra de lo que a costa de grandes sacrificios habían rechazado. En consecuencia, asentaba que los únicos terrenos que podían ser susceptibles de venderse y colonizarse sin perjuicio de las poblaciones eran los que estaban fuera del alcance de los labradores de la península, es decir, aquellos ubicados en los confines del suroeste, sur y sureste de la península, así como en la isla de Cozumel. No obstante, instaba al gobierno a tener cautela económica y política al enajenar dichos terrenos a colonos extranjeros 
para no tener que llorar lo que México lloraba respecto a Texas, cuyos colonos se habían sublevado. ${ }^{24}$

Todo parece indicar que la consulta efectuada por la legislatura y el gobierno a los pueblos se realizó sólo para cubrir las apariencias. El día 5 de abril de 1841, el Congreso emitió una nueva ley de colonización cuyas principales características eran:

1. La restricción del ejido de los pueblos a una legua cuadrada, además de que se tenían que respetar los terrenos de dominio particular que quedasen comprendidos en esa extensión.

2. La declaración de enajenables de aquellos terrenos que ya se habían contemplado en la ley de colonización de 1825 y, además, los de los litorales del oriente, así como otras zonas del suroeste, sur y sureste de la península, es decir, lo que hoy en día vendrían siendo dos terceras partes de los actuales estados de Quintana Roo y Campeche. Sin embargo, advertía que no se podían enajenar los terrenos de los ejidos que la misma ley designaba a los pueblos y los de comunidad, sobre los cuales nada decía respecto a su sustento legal, su extensión o algo que pretendiera definirlos. ${ }^{25}$

La nueva ley de colonización implicaba la venta de muchos de los terrenos que se encontraban ocupados por labradores y criadores de ganado, tanto por aquellos que sin ser propietarios de terrenos contaban con licencia del gobierno para sus labores como por aquellos considerados clandestinos, por no contar con dicho permiso. Es por eso que otros artículos de la ley dispusieron dar la preferencia a los primeros en la adjudicación en propiedad de los terrenos que ocupaban o, en caso de no estar interesados, dispusieron que se les indemnizara por las mejoras efectuadas en el terreno. Respecto a los clandestinos, solamente podían ser acreedores a esa misma indemnización, es decir, sin la gracia de ser preferidos en la venta de los terrenos.

${ }^{24}$ El Siglo XIX, Mérida, 2 de marzo de 1841.

${ }^{25}$ Aznar Pérez, 1850, t. II, pp. 116-119.
En este sentido, la ley acarreaba una crítica situación para todos aquellos labradores y criadores que habían estado gozando del derecho usufructuario o de posesión, pues como lo había plasmado la junta municipal de Chancenote, casi todos ellos eran de escasos recursos para pretender adquirir una propiedad. Tal vez el único resquicio que les daba la ley era que al solicitarse la enajenación de algún terreno, el pueblo más cercano a él debía certificar si pertenecía o no a su ejido o a su propiedad comunal, y en caso de que así fuera y se pudiese demostrar, se ponían a salvo de la enajenación. Pero el Congreso y el gobierno habían prevenido esa situación y desde febrero de 1841 estaban buscando la forma de hacer eficaz el cobro de los arrendamientos a los agricultores que labraban en los terrenos comunales y baldíos, tal como estaba dispuesto en un decreto de $1824 .{ }^{26}$ Cabe decir que este impuesto nunca había podido recaudarse con regularidad en la península, por su fácil evasión.

Sin embargo, la incipiente aplicación de la ley de colonización quedó en suspenso, y luego fue reorientada en 1842 para estimular mediante premios con tierras la participación de la población civil para afrontar la invasión de las tropas del gobierno central mexicano. Hacia fines de 1843, al concluir el conflicto, fueron reactivadas las disposiciones de la ley de colonización contempladas para la enajenación de tierras, pero sus objetivos originales se vieron debilitados por los premios y por las deudas contraídas por efecto de la guerra. Además, la reanudación se desarrolló en un clima enrarecido por una revuelta indígena acaecida simultáneamente a la guerra y cuyas consecuencias no pudieron pasar inadvertidas en los tribunales, e hicieron presagiar "incalculables males", si no se aplicaba un castigo ejemplar a los culpables que habían atentado contra dos haciendas de una de las familias más acaudaladas de la península. ${ }^{27}$

A pesar de estas circunstancias, las concesiones de tierras fueron vistas por el gobierno yucateco como una panacea para sus apremios económicos, pero al intentar llevarlas a la práctica se vio obligado a redefinir la dimen-

\footnotetext{
${ }^{26}$ El Siglo XIX, Mérida, 23 y 26 de febrero de 1841.

27 Sobre esta revuelta véase Güémez Pineda, 1992: 167-202.
} 
sión de los ejidos de los pueblos, así como su posición respecto a los establecimientos — sobre todo rancherías indígenas- situados en sus jurisdicciones o fuera de ellas, y también los parámetros para reconocer las tierras que se ostentaran como del común de los pueblos. Estos contratiempos, sumados a desencantos — como la súbita estimación de que las tierras no eran suficientes para cubrir la demanda y la posible desbandada de los labra-

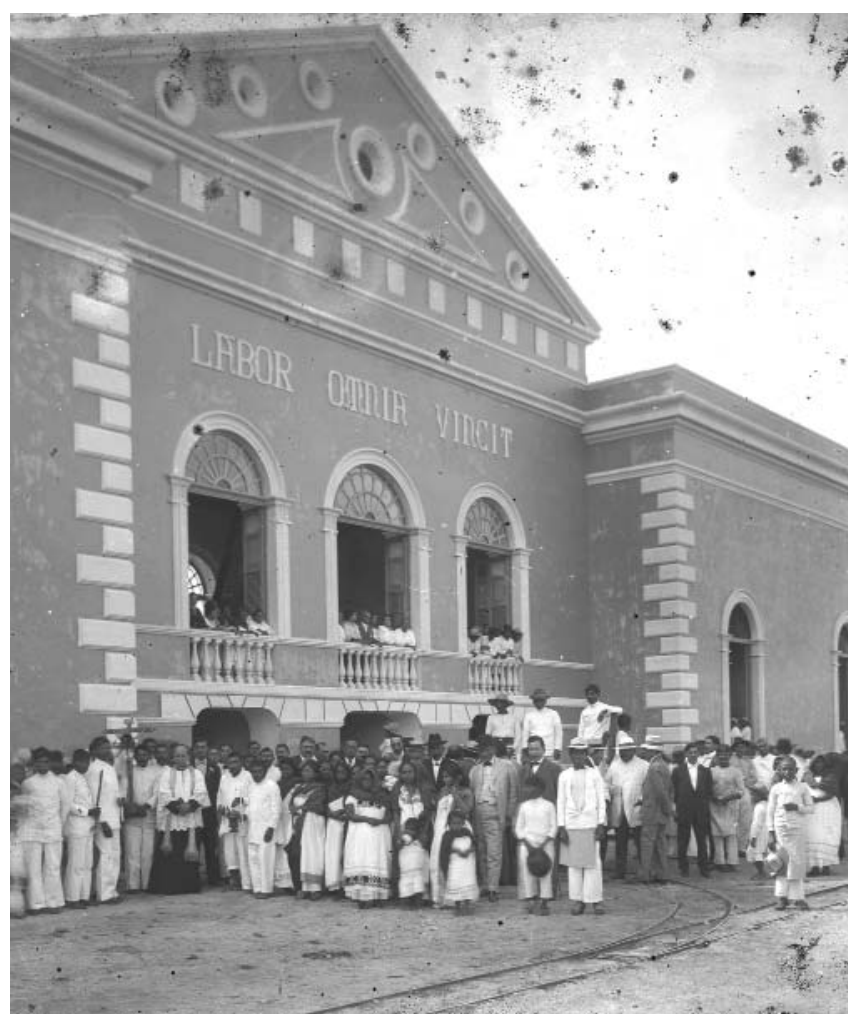

Hacienda "Sacapu", sala de máquinas, 1908 / Fototeca Pedro Guerra, Universidad Autónoma de Yucatán. dores indígenas como efecto de las concesiones- y obstáculos - como la resistencia de los afectados interpretada por el mismo gobierno como "un clamor general de todos los pueblos" y expresada, sobre todo, a través de acciones de las repúblicas de indígenas y las corporaciones municipales - permanecían latentes y comenzaban a escribir el epitafio de la ley de colonización.
La legislatura y el gobierno, a pesar de la tensión política y social que se vivió en la península debido principalmente a las constantes desavenencias diplomáticas y armadas con el gobierno general mexicano en los años de 1841 a 1845, tendieron en esta etapa a la consolidación y aclaración de las disposiciones sobre la enajenación de tierras (el destino de los ingresos obtenidos de ella, las dimensiones de los ejidos y ultimátums para efectuar su delimitación, reglamentos de mensuras, etc.), ${ }^{28}$ así como sobre el arrendamiento de tierras comunales y baldías, sobre todo para reorganizar el cobro del impuesto correspondiente. ${ }^{29}$

Las denuncias de tierras por parte de los interesados pudientes y medianopudientes no demoraron en presentarse en las oficinas gubernamentales. Sin embargo, fue tenaz la resistencia de los labradores por medio de protestas o representaciones interpuestas por ellos mismos o a través de los cabildos indígenas o de las autoridades de las corporaciones municipales. ${ }^{30}$

A fines de agosto de 1846, el diputado Francisco Martínez de Arredondo manifestaba ante el Congreso extraordinario que eran "repetidos los estorbos" que presentaban las autoridades de "algunos" pueblos para llevar a efecto la enajenación de tierras baldías, pues alegaban que los terrenos denunciados eran de su común. tes que antiguamente formaban las repúblicas de indígenas para mensurar los límites de sus pueblos. Por lo tanto, la principal propuesta de Martínez de Arredondo era que esos documentos no fueran considerados como títulos de propiedad y solamente fueran aceptados como tales los que demostraran ser legales por Expresaba que para ello se valían de expedien-

\footnotetext{
28 Aznar Pérez, 1850, t. II, pp. 288, 318, 347, 350-351, 353-355, 484 ${ }^{29}$ Aznar Pérez, 1850, t. II, pp. 352-353, 368, 371-372, 484; t. III, p. 47; El Siglo XIX, Mérida, 22 de octubre de 1844.

${ }^{30}$ En el Archivo General del Estado, especialmente en ramos de tierras y gobernación de Fondo, en Poder ejecutivo se encuentran diversos documentos que dan cuenta de esta disposición de labradores y autoridades de repeler los efectos de las pretendidas privatizaciones.
} 
real merced, donación formal o compra hecha por el común. ${ }^{31}$ La propuesta de Martínez de Arredondo fue combatida casi inmediatamente. El periódico campechano La Chismografía publicó un conjunto de artículos en septiembre y octubre en defensa de la propiedad comunal. Se señalaba que los documentos de las repúblicas de indígenas eran tan válidos como una real merced o que, inclusive, sin esos documentos no se debía perturbar la quieta y pacífica posesión que disfrutaban los pueblos desde tiempo inmemorial, pues tal posesión era "legítima, antigua, notoria y constante", y de ella daban testimonio signos, amojonamientos, linderos preexistentes, el reconocimiento de los propietarios, de las autoridades y corporaciones y jamás los labradores habían suplicado licencia para emprender sus labores, es decir, nunca habían pagado, ni se les había reclamado arrendamiento. También se procuró demostrar que tanto la Constitución de 1825 como la de 1841 y otras leyes, inclusive la de colonización de 1841, daban su amparo tanto a la propiedad individual como a la propiedad de las corporaciones. 32

La enajenación de tierras se fue llevando a efecto, pero no con la facilidad que el gobierno hubiese querido. Así fue hasta que una escisión del grupo en el poder, a fines de 1846, dio la pauta para que el asunto de la venta de tierras baldías pasara a ser la bandera política de los grupos contendientes para ganarse la simpatía popular.

Antes de referirnos a este asunto, conviene saber que en noviembre de 1846, justamente cuando Estados Unidos comenzaba su invasión al territorio mexicano, el gobierno general, encabezado por Antonio López de Santa Anna, había llegado también a un acuerdo con el gobierno yucateco que presidía Miguel Barbachano para que la península se reincorporara a la República. Esto fue suficiente para que un grupo de partidarios del ex gobernador Santiago Méndez, en diciembre de ese mismo año, emprendiera un movimiento que pronunciaba su desacuerdo con dicha reincorporación, declaraba la vigencia de la Constitución de 1841 y, de paso, también la neutra-

${ }^{31}$ Colección que contiene el proyecto..., 1847.

32 Ibidem. lidad de Yucatán en la guerra de México contra Estados Unidos. Asimismo — sin duda para atraer simpatizantes-, proponía reducir la contribución personal a un real y medio. Con esto estalla la guerra civil en la península. Los amotinados finalmente logran que el gobernador Barbachano dimitiera a fines de enero de $1847 \mathrm{y}$ nombran gobernador a Domingo Barret. Obviamente, se hicieron del poder en un clima de total incertidumbre, particularmente porque los indígenas reclutados por los golpistas para atacar a la ciudad de Valladolid no depusieron las armas.

Por su parte, los barbachanistas intentaron, a fines de febrero, volver al poder. En su plan contemplaban el reconocimiento de los tratados por los que Yucatán se había reincorporado a la República Mexicana, la vigencia de la Constitución mexicana de 1824 y la del estado de 1825 y nombraban como gobernador a Sebastián López de Llergo. Con fines proselitistas ofrecieron la reducción de la contribución personal a un real y exentar de ella a todos los que apoyaran al movimiento con armas o dinero. También ofrecieron "indemnizar" a los pueblos por los perjuicios que habían sufrido con la venta de las tierras de sus comunidades. ${ }^{33}$

Los barbachanistas ocuparon la ciudad de Mérida prácticamente sin oposición, puesto que el gobierno mendecista se había trasladado a Campeche. De ese modo, hubo en Yucatán dos grupos que gobernaron simultáneamente, aunque los barbachanistas no duraron ni siquiera un mes. En este corto tiempo, éstos solamente pudieron emitir dos decretos, ambos del 2 de marzo, y relativos a las promesas de su plan. Uno que declaraba la reducción de la contribución personal y otro que derogaba la ley de colonización del 5 de abril de 1841, que disponía la venta de terrenos del Estado. ${ }^{34}$ Sin embargo, el gobierno de Domingo Barret también mandó anular la ley de colonización en un decreto del 5 de marzo de 1847. Para mediados de marzo, el gobierno mendecista, ante la infructuosa arremetida barbachanista, volvió a erigirse como el único grupo gobernante. ${ }^{35}$

\footnotetext{
${ }^{33}$ Los términos del plan son tomados de una nota de Alonso Aznar Pérez incluida en su Colección de leyes y decretos, 1851, t. III, pp. 104-105. ${ }^{34}$ Véase ambos decretos en Aznar Pérez, 1851, t. III, pp. 105-106.

${ }^{35}$ Sobre estos acontecimientos político-militares véase Ancona, t. III,
} 


\section{LAS CONSECUENCIAS DE LA AGITACIÓN POLÍTICAY MILITAR QUE SE VIVIÓ EN LA PENÍNSULA DE 1840 A 1847}

El derrocamiento del gobierno centralista en el estado, las arremetidas del gobierno central mexicano contra los federalistas yucatecos y la escisión de éstos habían dado la oportunidad a la población indígena de tomar parte en estos conflictos, pero con su intervención de ningún modo había logrado subsanar significativamente su apremiante situación. Los ofrecimientos para enrolar a los indígenas solamente habían sido cumplidos a medias, pues las contribuciones eclesiásticas y civiles, aunque reducidas, continuaron cobrándose con rigor y, aunque la ley de colonización no había tocado fondo en los pueblos gracias a la férrea resistencia encabezada por las repúblicas de indígenas y autoridades de las corporaciones municipales, era un asunto que mantenía tensos a los labradores de los pueblos. Fue a sabiendas de esto que los barbachanistas y los mendecistas, como un recurso desesperado, ofrecieron reducir las contribuciones y frenar tos entre la población indígena.

Podemos concluir que la ley de colonización de 1841 propició finalmente un gran número de denuncias por parte de los interesados pudientes y medianopudientes que, como hemos visto, no demoraron en presentarse en las oficinas gubernamentales para tratar de agenciarse las tierras que suponían enajenables de acuerdo con dicha ley o sus decretos aclaratorios. Un balance realizado por Robert Patch con base en los registros de la época arroja que de 1843 a 1847 fueron denunciadas por lo menos unas 800 ooo hectáreas. Según esos mismos datos, el área del estado más afectada fue la jurisdicción del partido de Peto, en donde se encontraban más de un tercio de los terrenos baldíos, supuestamente transmutados en propiedad privada. Un $45 \%$ de esos terrenos se encontraban en las jurisdicciones de Peto, Hopelchén, Sotuta, Tekax y Valladolid, precisamente allí —enfatiza Patch“donde detonó con mayor intensidad la rebelión indíge-

pp. 461-486; respecto a la participación indígena en estos conflictos véase Rugeley, 1996, pp. 164-180. na”. Sin embargo, también reconoce que otras regiones fueron "casi igualmente perjudicadas", inclusive los resultados que arrojan sus datos le hacen dudar de la tesis propuesta por Cline, pues casi una cuarta parte de los terrenos baldíos enajenados estaban localizados en el noroeste de la península (la "región principal"), que era la zona más densamente poblada de Yucatán (las prefecturas y subprefecturas de Maxcanú, Mérida, Ticul, Hecelchakán, Motul, Izamal y Tecoh). ${ }^{36}$

Pero aquí cabe preguntarse: ¿fueron realmente ocupadas esas tierras? Consideramos que no, en primer lugar, porque las denuncias no implicaron necesariamente adjudicaciones; $y$, en segundo, las adjudicaciones no constituyeron una garantía de ocupación realmente hasta 1847. Esto debido, principalmente - y como en el mismo seno del Congreso se reconocía-, a la tenaz oposición que emanaba de las autoridades indígenas y municipales, situación que incluso indujo — con el afán de captar simpatizantes a su causa - a los dos grupos políticos (mendecistas y barbachanistas) que disputaban, y simultáneamente ostentaron, el poder a mediados de 1846 a derogar la ley de colonización en marzo de 1847 y a ofrecer una "indemnización” a los pueblos afectados, cinco meses antes del inicio de la llamada guerra de castas.

Por otra parte, actualmente se calcula que los tres estados que integran la península (Yucatán, Campeche y Quintana Roo) tienen juntos una superficie de 14 millones de hectáreas, es decir, unas 8000 leguas cuadradas. Las 800 ooo hectáreas denunciadas como baldíos equivalían a unas 460 leguas. Pero para nuestros propósitos y a fin de entender las preocupaciones de la época, conviene recordar que en 1844 el gobernador aludía que eran insuficientes las tierras para los premios de campaña, así como para amortizar la deuda pública y la venta de terrenos que se promovía. En ese tiempo los datos más confiables arrojaban que la península contaba con 7285 leguas cuadradas, de las cuales 2500 eran terrenos cenagosos, 960 correspondían a ejidos, 1500 estaban en manos de propietarios privados y 920 se excluían de las enajenables. Quedaban, pues 1405 que podían enajenarse. En

\footnotetext{
36 Patch, 1983: 17-26, 1990: 45-95.
} 
resumen, las 460 leguas denunciadas no representaban más del $7 \%$ del total de la superficie peninsular y un $32 \%$ de las tierras consideradas enajenables en aquel tiempo.

Con base en estos números no pareciera que el problema haya sido severo para los pueblos, pero hay que hacer notar que no se tomaba en cuenta la superficie de los terrenos comunes, los cuales eran un enigma para el gobierno - tal vez sucedía lo mismo con las extensiones ocupadas por propiedades particulares indígenas-. De ahí emergía el principal problema para llevar a cabo el proceso de privatización decimonónico. No hay duda, pues, que en la primera mitad del siglo XIX muchos pueblos podían considerarse como los poseedores de tierra más opulentos. Aunque de hecho, las tierras denunciadas solamente representaban un $32 \%$ de las consideradas enajenables, la mayoría de los denunciantes pretendía tierras cercanas a los pueblos o a los ranchos anexos, lo cual se traducía, por lo general, en pretender arrancarlas del dominio de los usufructuarios del común. Y para esto había una razón simple, pero fundamental, la mayor parte de las tierras enajenables se encontraban donde muy pocos las querían, es decir, en zonas semidespobladas e inhóspitas de los extensos distritos de Tekax y Campeche.

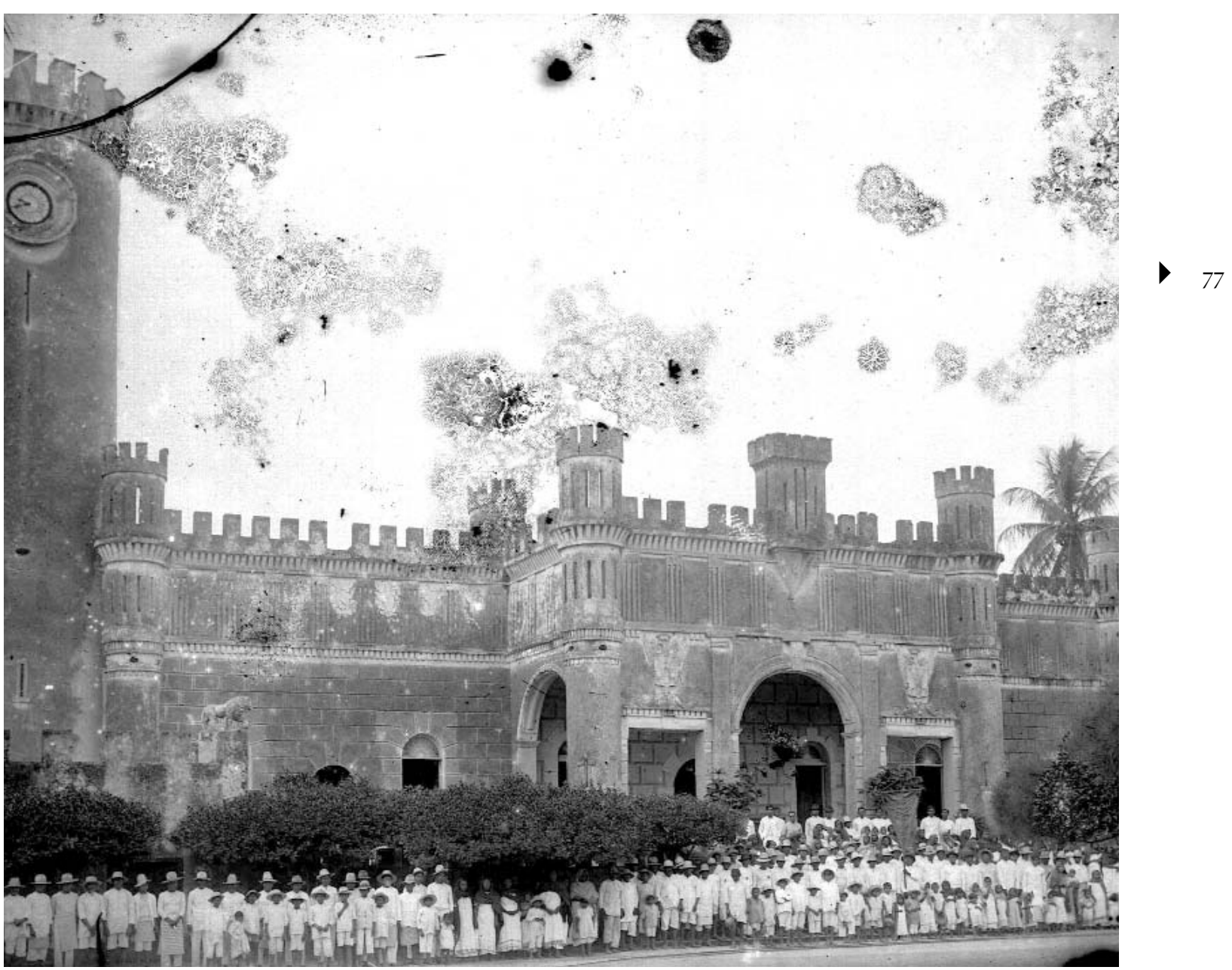

Hacienda henequenera "Chenchen de las Torres", 1915 / Fototeca Pedro Guerra, Universidad Autónoma de Yucatán. 


\section{CONSIDERACIONES FINALES}

El proceso de adaptación de las ideas liberales en Yucatán en torno a la posesión de la tierra de 1812 a 1847 estuvo estrechamente vinculado a la pugna por el poder político, protagonizada por dos grupos con distintas aspiraciones. De ese modo, aquel sagrado derecho de todos los individuos a la propiedad había sido, en una primera instancia, pragmatizado por los liberales yucatecos para subsanar en parte las carencias del erario y en beneficio de un grupo mediano pudiente y pro ganadero; en un segundo momento, durante el centralismo, se redujo a la protección del sagrado derecho de propiedad de la antigua oligarquía agraria poseedora de haciendas con ganado y tierras de arriendo. Por último, desembocó en un liberalismo pragmático a ultranza amparado bajo la ley de colonización de 1841, en beneficio de grupos de individuos medianamente pudientes y pudientes que se agenciaron o pretendieron concesiones a costa de las tierras de usufructo comunal.

Sin embargo, los hechos nos demuestran que el pro- viese el de favorecer a esta actividad y tampoco la información generada por su aplicación da pie para pensar que haya sido beneficiada. En contraste, sobran evidencias de que los interesados por la adquisición de tierras eran, por lo general, individuos de un grupo intermedio que pretendía incursionar en la ganadería y que sus propósitos se vieron reflejados en las leyes. Hasta 1840, por lo menos, no parece que los empresarios dedicados a la agricultura, como lo eran los grandes cultivadores de maíz o los productores de azúcar, hayan pretendido —al menos no de manera significativa - tierras en propiedad, y tampoco que su actividad haya generado una inquietud entre los labradores de los pueblos, como lo ocasionaban los establecimientos ganaderos. La carencia de información sobre disputas entre los cultivadores de caña y los labradores indígenas dedicados de manera prioritaria a la milpa parece indicar que las actividades de ambos no fueron incompatibles. Incluso cabe la posibilidad de que muchos indígenas se hayan empleado como jornaleros en los cañaverales desempeñando al mismo tiempo, o de manera alterna, sus actividades como milpero.

La ley de colonización de 1841, en efecto, tenía toda la intención de favorecer a la actividad agrícola en general y bien pudo ser un detonante para que los cultivadores de caña se volcaran a la adquisición de tierras. Empero, la ley no se puso en vigor si no hasta fines de 1843 y para febrero de 1844 - año en que se habían cultivado poco más de cien mil mecates de caña— las expectativas de la industria eran negativas a raíz de que el gobierno de México prohibió la introducción del azúcar y aguardiente yucateco en los puertos de la República. De hecho, en los años de 1845 y 1846, ante la saturación del mercado interno y la falta de canales de exportación "hubo cañaveralistas —asienta Aznar Barbachano en el periódico Las Mejoras Materiales - que se vieron en la triste necesidad de entregar a las llamas sus planteles antes de sufrir una pérdida mayor, convirtiéndolos en azúcar o aguardiente que nadie les compraba". 38 El beneficio de la "industria" azucarera no fue, pues, un objetivo específico de la ley de

${ }^{37}$ Esta es una interpretación que desde 1947 fue difundida por Howard F. Cline a través de su artículo "The Sugar Episode in Yucatán, 18251850", en la revista Inter-American Economic Affairs. Véase una versión en español en Cline, 1978: 3-15. La interpretación de Cline ha sido seguida por distintos autores tales como Reed, 1970; Bartolomé y Barabas, 1981: 20-22; Patch, 1983: 17-26, 1990: 45-95; Quintal Martín, 1976: 60-89; Bricker, 1993: 178-186.
${ }^{38}$ Aznar Barbachano, 1957: 1-2 y 46. Los capítulos que integran este trabajo fueron publicados originalmente en 1858 en el único volumen del periódico Las Mejoras Materiales, editado en la ciudad de Campeche. 
colonización; mucho menos se puede decir que haya sido uno de sus mejores resultados y, por añadidura, no se puede considerar como una de las causas de la guerra de castas, aunque ciertamente resultó severamente dañada por ésta, pues la producción alcanzada en 1844 no pudo mantenerse en años posteriores. Con la guerra, parte de las siembras se destruyeron, otras fueron abandonadas, de ahí que en los años inmediatos al inicio del conflicto no sólo no hubo exportación de azúcar, sino que la producción no alcanzaba ni para el consumo interno, por lo que se tuvo que importar de la vecina isla de Cuba. ${ }^{39}$

Un suceso digno de mencionarse y que apoya nuestra intención de desvincular el factor agrario con la guerra de castas es la presencia de Jacinto Pat, uno de los principales líderes de la insurrección indígena, entre los diez individuos de apellido maya que denunciaron tierras al calor de la ley de colonización de 1841. Pat reclamó el 10 de agosto de 1846 media legua de tierras cerca de Tihosuco, pueblo del que era su cacique. Robert Patch, quien nos proporciona esta información, interpreta esta acción de Pat en el sentido de que era "el menos radical en sus puntos de vista”. Sin embargo, consideramos que es una evidencia contundente de que el "plan" de la rebelión - si es que realmente estaba siendo proyectada - no contemplaba una redención de carácter agrario.

Es también cuestionable que esta arremetida de los años 1840 haya propiciado el "avance definitivo" de la gran propiedad en Yucatán y que haya significado la base del auge que las haciendas henequeneras comenzaron a tener durante la segunda mitad del siglo XIX. ${ }^{40}$ Sin duda, tal consolidación tuvo que ver con otro proceso iniciado después de los momentos más intensos de la guerra, pues el proyecto privatizador derivado de dicha ley de colonización no pudo sobrevivir ni siquiera en el noroeste, región donde estaba la capital yucateca y espacio que el poder "blanco" pudo recuperar en los años inmediatos al

\footnotetext{
${ }^{39}$ Ibidem.

${ }^{40}$ Por ejemplo, José Luis Sierra, al referirse a los aspectos importantes que propiciaron el estallido de la guerra de castas señala, entre otros, "el avance definitivo de la propiedad privada sobre los terrenos nacionales y realengos o nacionales". "Prólogo", en Baranda, 1991, t. I, p. 42; Bracamonte, 1993, también tiene una concepción similar.
}

estallido de la guerra de castas. Las plantaciones henequeneras se desarrollaron, de manera exclusiva, en una zona donde desde el siglo XVIII se había consolidado un grupo importante de hacendados. En el resto de las extensas tierras de la península no se desarrolló, al menos durante todo el siglo XIX $-\mathrm{y}$ tampoco en el siglo XX-, ningún emporio similar al del henequén ni mucho menos. Por lo tanto, se puede hablar de un fracaso de los proyectos de corte liberal en Yucatán, cuyos objetivos eran, sobre todo, poner en manos de propietarios yucatecos, nacionales y extranjeros la mayor parte de los terrenos de la península, especialmente aquellos territorios pertenecientes al actual estado de Quintana Roo, que durante toda la segunda mitad del siglo XIX fueron considerados zona insegura o estuvieron en manos de las comunidades mayas rebeldes que se asentaron en la península. Ocupación que, por cierto, solucionó paradójicamente el problema del insistente avance inglés sobre el territorio peninsular que no había podido frenar el gobierno yucateco con sus proyectos para colonizar la región situada al norte del Río Hondo. ${ }^{41}$

El fracaso de los proyectos de corte liberal en la península yucateca no fue excepcional. Una revisión de casos de distintas regiones de la República Mexicana enfatizan de algún modo esa frustración liberal en la política sobre la tierra. A pesar de los distintos enfoques que utilizan para aproximarse al problema en torno a la tierra, el común denominador es el fracaso de las clases políticas al tratar de imponer las leyes liberales para la desamortización de los terrenos comunales, proceso que, como dice Knowlton, su mejor caracterización es la de interminable. ${ }^{42}$

Los proyectos de privatización de tierras ocasionaron, indudablemente, malestares a los comuneros de los pueblos, pero es cuestionable que hayan incidido como uno de los motivos que causaron la sublevación indígena, como lo han afirmado diversos autores — desde Sierra O'Reilly y Howard F. Cline hasta Robert Patch-, su influencia, en todo caso, debió ser secundaria al problema fiscal o el político-militar que llevó a hacer partícipes

\footnotetext{
41 Sobre este asunto véase Güémez Pineda, 1997: 163-195.

42 Sobre esta apreciación véase por ejemplo Menegus, 1995: 7-28; Ducey, 1989: 209-330; Knowlton, 1978: 3-26 y Mallon, 1994: 69-106.
} 


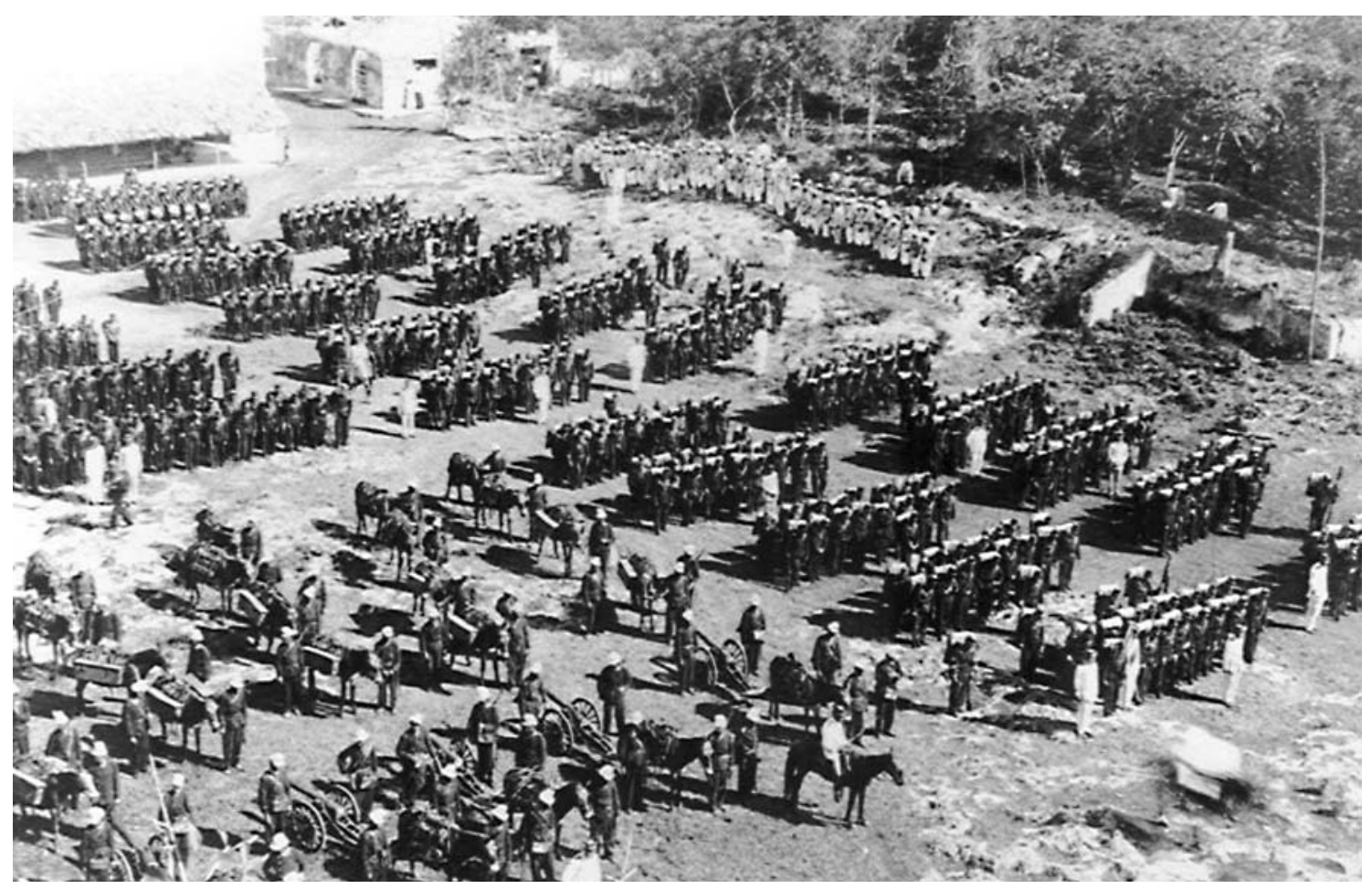

Batallones federales, Santa Cruz de Bravo, 1906 / Centro de Apoyo a la Investigación Histórica en Yucatán.

a los indígenas de las pugnas de la élite. Esa lucha - como otras guerras de castas que se registraron en México a partir de 1840 - no puede describirse adecuadamente como agrarista, porque el calificativo no expresa su complejidad, sino que la reduce a su manifestación más evidente. Los indígenas o campesinos, sin duda, estaban luchando contra una compleja ofensiva jurídica y política y no sólo por la tierra. Asumimos la postura que ha señalado que los rebeldes de las guerras de castas en México estaban luchando, esencialmente, para conservar un territorio que no era sólo una superficie, sino la razón de su existencia, la base de su personalidad jurídica, de su ser civil y de sus derechos tradicionales contra los que atentaban los que encarnaban el poder regional "ladino".43 El problema agrario ha sido considerado por diversos investigadores como una de las causas principales de las insurrecciones indígenas y campesinas. De manera auto-

\footnotetext{
43 Pastor, 1993: 98-99.
}

mática, los movimientos de rebeldía se han vinculado con problemas de tierras o con móviles mesiánicos y religiosos. Sin embargo, la investigación histórica basada en el análisis de fuentes documentales ha demostrado que ni la rebelión yaqui de 1740 — a la que J. Meyer (1973) le atribuyó un móvil predominantemente agrario — ni las que ocurrieron durante la primera mitad del siglo XIX tuvieron como móvil principal el problema de la tierra. ${ }^{44}$

Michael T. Ducey, en un trabajo relativo al norte de Veracruz, alude que mucho de lo escrito sobre el asunto de las tierras comunales se discute en torno a los instrumentos jurídicos introducidos para enajenar la propiedad indígena y hace una crítica a este énfasis jurídico de la historiografía, a partir del hecho de que no toma en cuenta la participación del campesinado indígena en la

\footnotetext{
${ }^{44}$ Hernández Silva, 1993: 296. Los levantamientos rurales en México tienen ya una larga trayectoria como preocupación de estudiosos de distintas regiones de México; entre las obras que han intentado explicar la complejidad de los patrones de las insurrecciones destacan la de John Tutino, 1990(b), y la coordinada por Friedrich Katz, 1990.
} 
modificación de dichas leyes. En el mismo sentido, se opone a la idea, bastante generalizada, de vincular obligadamente a las rebeliones campesinas con los descontentos que ocasionaban los despojos o cambios en la tenencia de la tierra. El norte de Veracruz experimentó un gran número de revueltas de 1830 a 1870, las cuales se han atribuido a despojos de tierras. Empero, su investigación señala que, por el contrario, fueron épocas en las que los campesinos aumentaron la extensión de sus tierras de comunidad o cambiaron su estatus de arrendatarios a pequeños propietarios a costa de los terratenientes tradicionales. Por lo tanto, no encuentra relación entre despojos y rebeliones, ya que todo parece indicar que las rebeliones de los campesinos del siglo XIX no fueron reacciones a despojos recientes, sino acciones diseñadas para conseguir tierra que no había estado en sus manos. Advierte que se requiere de un análisis más complejo para explicar el radicalismo campesino de su región de estudio antes del Porfiriato, ya que no es posible identificar los despojos de tierras como la causa de las rebeliones, simplemente porque no los hubo ${ }^{45} \mathrm{o}$ no pudieron concretarse a pesar de los intentos. Este también fue el caso yucateco, en el que existen suficientes muestras de que los labradores de los pueblos y sus autoridades podían sobrellevar, revertir o, por lo menos, restringir los efectos de los proyectos de privatización sin recurrir a una confrontación armada.

\section{Bibliografía}

Ancona, Eligio, 1879, Historia de Yucatán desde la época más remota hasta nuestros días, t. III, Imprenta de Manuel Heredia Argüelles, Mérida.

Aznar Barbachano, Tomás, 1957, La caña de azúcar en Yucatán (1858), México, Banco Nacional de Crédito Agrícola y Ganadero.

Aznar Pérez, Alonso (comp.), 1850, Colección de leyes decretos, órdenes o acuerdos de tendencia general del poder legislativo del estado libre y soberano de Yucatán, formada por... y publicada por Rafael Pedrera con autorización del gobierno. Tomo segundo que comprende todas las disposi-

45 Ducey, 1989: 209-330. ciones legislativas, desde el 1 de enero de 1841 hasta 31 de diciembre de 1845 , t. II, Imprenta del Editor, Mérida.

- (comp.), 1851, Colección de leyes decretos, órdenes o acuerdos de tendencia general del poder legislativo del estado libre y soberano de Yucatán, formada por... y publicada por Rafael Pedrera con autorización del gobierno. Tomo tercero que comprende todas las disposiciones legislativas, desde el 1 de enero de 1846 hasta fin de diciembre de 1850 , t. III, Imprenta del Editor, Mérida.

Bartolomé, Miguel A. y Alicia M. Barabas, 1981, La resistencia maya. Relaciones interétnicas en el oriente de la península de Yucatán, col. Científica, 53, INAH, México.

Bracamonte, Pedro, 1993, Amos y sirvientes. Las haciendas de Yucatán, 1789-1860, Mérida, Universidad Autónoma de Yucatán.

—_ y Gabriela Solís, 1996, Espacios mayas de autonomía. El pacto colonial en Yucatán, Mérida, Universidad Autónoma de Yucatán, Conacyt.

Bricker, Victoria Reifler, 1993, El Cristo indígena, el rey nativo. El sustrato histórico de la mitología del ritual de los mayas, FCE, México.

Cline, Howard F., 1947, "Regionalism and Society in Yucatán: Progressivism and the Origins of the Caste Ward, 1825-1847", tesis doctoral, Harward, .

_ 1950, "Related Studies in Early Nineteenth Century Yucatecan Social History", Microfilm Collection of Manuscripts on Middle American Anthropology, XXXII, University of Chicago Library, Chicago.

, 1978, "El episodio azucarero en Yucatán (1825-1850)", Yucatán, Historia y Economía, núm. 5, enero-febrero, pp. 3-23.

Colección que contiene el proyecto de acuerdo o decreto, presentado por el Sr. Diputado D. Francisco Martínez de Arredondo y leído en la sesión del A. Congreso extraordinario el día 27 de agosto de 1846.- Siglo 19, num. 797, y artículos impresos en el periódico "La Chismografía" de Campeche, en favor del derecho de posesión y propiedad de los pueblos, sobre sus terrenos comunes, y la última y principal parte de su defensa, y la refutación de ese proyecto que quedó inédita por haber cerrado sus columnas dicho periódico, $y$ que ahora se imprime en obsequio del bien $y$ derecho de dichos pueblos, Campeche, 1847 , impreso por José M. Peralta.

Ducey, Michael T., 1989, "Tierras comunales y rebeliones en el norte de Veracruz antes del porfiriato, 1821-1880: el proyecto liberal frustrado", Anuario VI, pp. 209-330.

Franco Mendoza, Moisés, 1986, "La desamortización de bienes de comunidades indígenas en Michoacán”, en Pedro Carrasco, et al., La sociedad indígena en el centro y occidente de México, El Colegio de Michoacán, Zamora, pp. 169-188. 
Frazer, Donald, 1972, "La política de desamortización en las comunidades indígenas (1856-1872)", Historia Mexicana, vol. XXI (4), núm. 84, abril-junio, pp. 615-652.

González Navarro, Moisés, 1970, Raza y tierra: la guerra de castas y el henequén, El Colegio de México, México.

Güémez Pineda, Arturo, 1992, "La rebelión de Nohcacab. Prefacio inédito de la guerra de castas", Relaciones. Estudios de Historia y Sociedad, núm. 52, Zamora, pp. 167-202.

- 1994, Liberalismo en tierras del caminante. Yucatán, 1812-1840, El Colegio de Michoacán / Universidad Autónoma de Yucatán, Zamora.

_ 1997 , "Comunidades indígenas rebeldes y colonización en Yucatán: la paradójica solución a un proyecto criollo", Relaciones. Estudios de Historia y Sociedad, núm. 69, Zamora, invierno, pp. 163-195.

Hernández Silva, Héctor Cuauhtémoc, 1993, "El Valle del Yaqui y los proyectos económicos de las elites regionales de Sonora. 1830-1857", en Antonio Escobar O., Indio, nación y comunidad en el México del siglo XIX, México, Centro de Estudios Mexicanos y Centroamericanos/CIESAS, pp. 293-302.

Katz, Friedrich, 1988, Revuelta, rebelión y revolución. La lucha rural en México del siglo XVI al siglo XX, Era, México.

Knowlton, Robert J., 1978, "La individualización de la propiedad corporativa civil en el siglo XIX: notas sobre Jalisco", Historia Mexicana, vol. XXVIII (1), núm. 109, julioseptiembre, pp. 24-61.

_-, 1990, "La división de tierras durante el siglo XIX", Historia Mexicana, vol. XL (1), núm. 157, pp. 3-26.

Lapointe, Marie, 1983, Los mayas rebeldes de Yucatán, El Colegio de Michoacán, Zamora.

Mallon, Flortencia, 1994, "Reflections on the Ruins: Everyday forms of the State Formation in Nineteenth-Century Mexico", en Gilbert Joseph and Daniel Nugent (eds.), Everyday Forms of The State Formation, Revolution and the Negotiation of the Rule in Modern Mexico, Duke University Press, Estados Unidos-Londres, pp. 69-106.

Márquez, Enrique, 1986, “Tierra, clanes y política en la Huasteca potosina (1797-1843)", Revista Mexicana de Sociología, vol. XLVIII, núm. 1, pp. 201-115.

Menegus, Margarita, 1995, "La desamortización de bienes comunales y municipales en el Valle de Toluca (1800-1854), siglo XIX", Cuadernos de Historia, Universidad Autónoma de Nuevo León, año IV, núm. 12, mayo-agosto, pp. 7-27.

Meyer, Jean, 1986, "La Ley Lerdo y la desamortización de las comunidades en Jalisco", en Pedro Carrasco, et al., La sociedad indígena en el centro y occidente de México, El Colegio de Michoacán, Zamora, pp. 189-211.

Pastor F., Rodolfo, 1993, "Desamortización, regionalización del poder y guerras de castas, 1822 a 1862: un ensayo de interpretación", en Jorge Padua y Alain Vanneph (coords.), Poder local, poder regional, México, El Colegio de México/Centre D'Études Mexicaines et Centramericaines, pp. 89-105.

Patch, Robert, 1976, "La formación de estancias y haciendas en Yucatán durante la Colonia", Boletín de la Escuela de Ciencias Antropológicas, vol. 4, núm. 9, pp. 21-61.

_ 1983 , "El fin del régimen colonial en Yucatán y los orígenes de la guerra de castas: el problema de la tierra, 18121846", Boletín de la Escuela de Ciencias Antropológicas, vol. 10, núm. 6o, pp. 17-26.

— 1990 , "Descolonización, el problema agrario y los orígenes de la guerra de castas, 1812-1847", en Othón Baños Ramírez, Sociedad, estructura agraria y estado en Yucatán, Mérida, Universidad Autónoma de Yucatán, pp. 45-95.

Quezada, Sergio, Arturo Güémez y Carlos Tapia, 1986, Bibliografía comentada sobre la cuestión étnica y la guerra de castas, 1821-1910, Universidad Autónoma de Yucatán/ Secretaría de Educación Pública, Mérida.

Quintal Martín, Fidelio, 1976, "Interpretación de la guerra campesina de Yucatán de 1847”, Revista de la Universidad de Yucatán, vol. 18, núm. 104, pp. 60-89.

Radding, Cynthia, 1993, "Etnia, tierra y Estado: la nación ópata de la sierra sonorense en la transición de Colonia a República”, en Antonio Escobar O. (coord.), Indio, nación y comunidad en el México del siglo XIX, Centro de Estudios Mexicanos y Centroamericanos / CIESAS, México, pp. 267-292.

Reed, Nelson, 1970, La guerra de castas de Yucatán, Era, México.

Reina, Leticia, 1989, "De la agroexportación a la producción de autoconsumo. Las comunidades indígenas de Oaxaca, 1776-1856", Tzintzun, núm. 10, pp. 19-35.

Rugeley, Terry, 1996, Yucatan's Maya Peasantry and the Origins of the Caste War, University of California Press, Austin.

Sierra, José Luis, 1991, "Prólogo", en Joaquín Baranda, Recordaciones Históricas, t. I, Conaculta, México, pp. 37-50.

Sierra O'Reilly, Justo, 1954, Los indios de Yucatán. Consideraciones históricas sobre la influencia del elemento indígena en la organización social del país, 2 tomos, Compañía Tipográfica Yucateca, Mérida.

Tutino, John, 1990(a), "Cambio social agrario y rebelión campesina en el México decimonónico: el caso de Chalco", en Friedrich Katz, Revuelta, rebelión y revolución. La lucha rural en México del siglo XVI al siglo XX, Era, México, t. I., pp. 94-134.

— $1990($ b), De la insurrección a la revolución en México. Las bases sociales de la violencia agraria 1750/1940, Era, México. 